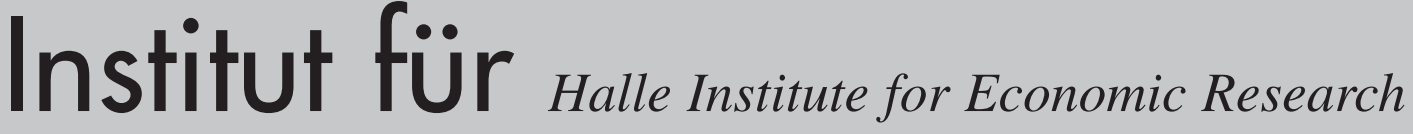 Wirtschaffsforschung Halle
}

\section{Is the European Monetary Union an Endogenous Currency Area? The Example of the Labor Markets}

Herbert S. Buscher and Hubert Gabrisch

\section{IWH-Diskussionspapiere IWH-Discussion Papers}




\section{Is the European Monetary Union an Endogenous Currency Area? The Example of the Labor Markets}

Herbert S. Buscher and Hubert Gabrisch 
Autors: The Halle Institute for Economic Research (IWH)

Kleine Märkerstraße 8, 06108 Halle (Saale)

Dr. Hubert Gabrisch

E-Mail: Hubert.Gabrisch@iwh-halle.de

Phone: +49 34577 53-830

Dr. Herbert S. Buscher

E-Mail: Herbert.Buscher@iwh-halle.de

Phone: +49 34577 53-770

The responsibility for discussion papers lies solely with the individual authors. The views expressed herein do not necessarily represent those of the IWH. The papers represent preliminary work and are circulated to encourage discussion with the author. Citation of the discussion papers should account for their provisional character; a revised version may be available directly from the author.

Comments and suggestions on the methods and results presented are welcome.

IWH-Discussion Papers are indexed in RePEc-Econpapers and in ECONIS.

Herausgeber:

INSTITUT FÜR WIRTSCHAFTSFORSCHUNG HALLE - IWH

Prof. Dr. Ulrich Blum (Präsident), Dr. Hubert Gabrisch (Forschungsdirektor)

Das IWH ist Mitglied der Leibniz-Gemeinschaft

Hausanschrift:Kleine Märkerstraße 8, 06108 Halle (Saale)

Postanschrift: Postfach 1103 61, 06017 Halle (Saale)

Telefon:

(0345) 77 53-60

Telefax: $\quad$ (0345) 77 53-8 20

Internetadresse: $\quad$ http://www.iwh-halle.de 


\title{
Is the European Monetary Union an Endogenous Currency Area? The Example of the Labor Markets
}

\begin{abstract}
Our study tries to find out whether wage dynamics between Euro member countries became more synchronized through the adoption of the common currency. We calculate bivarate correlation coefficients of wage and wage cost dynamics and run a model of endogenously induced changes of coefficients, which are explained by other variables being also endogenous: trade intensity, sectoral specialization, financial integration. We used a panel data structure to allow for cross-section weights for country-pair observations. We use instrumental variable regressions in order to disentangle exogenous from endogenous influences. We applied these techniques to real and nominal wage dynamics and to dynamics of unit labor costs. We found evidence for persistent asymmetries in nominal wage formation despite a single currency and monetary policy, responsible for diverging unit labor costs and for emerging trade imbalances among the EMU member countries.
\end{abstract}

JEL codes: F15, F40, J21, J23. 


\section{Is the European Monetary Union an Endogenous Currency Area? The Example of the Labor Markets}

\section{Zusammenfassung}

Die Studie untersucht, ob sich die Lohndynamik zwischen den Mitgliedsstaaten der Eurozone infolge der gemeinsamen Währung zu einer höheren Synchronisation hin bewegt hat. Wir berechnen bivariate Korrelationskoeffizienten der Lohn- und Lohnkostendynamik und schätzen ein Modell, in dem die mittleren Werte der Korrelationskoeffizienten auf erklärende Variablen regressiert werden, die selbst wiederum teilweise endogen sind: Handelsintensität, sektorale Spezialisierung und Finanzmarktintegration. Auf der Grundlage von Querschnittsdaten für die EMU-Länder, die jeweils gewichtet in die Regressionsanalyse eingehen, werden IV-Schätzungen präsentiert, um das Problem der Endogenität der erklärenden Variablen zu lösen. Dieser Ansatz wird sowohl für die Lohndynamik in realen und in nominalen Größen als auch für die Lohnstückkostenvariable verwendet. Die Ergebnisse verweisen auf persistente Asymmetrien in der nominalen Lohnvariablen - trotz einer einheitlichen Währung und einer gemeinsamen Geldpolitik -, was als eine der Ursachen für divergierende Lohnstückkosten und wachsende Handelsungleichgewichte unter den Staaten der Eurozone angesehen wird.

JEL codes: F15, F40, J21, J23. 


\section{Is the European Monetary Union an Endogenous Currency Area? The example of the Labor Markets}

\section{Introduction}

We analyze labor cost developments in Euro member states before and after the introduction of the Euro, and ask whether the single European currency will push the member countries into more market-coordinated (synchronized) wage formation, thereby easing the asymmetric nature of shocks. ${ }^{1}$

Our motivation for such an investigation is that wages, in particular unit labor costs of EMU countries diverge since Euro introduction in 1999, indicating a weaker relation between wage and productivity developments. De-synchronization in wage dynamics might reflect an asymmetric distribution of costs after economically and/or politically caused shocks, hence, a shift of competitive positions and current account imbalances with different impacts on employment and growth (see European Commission 2006). A national government may aggravate the market asymmetry by various tools, among others by replacing social taxes through higher indirect taxes or by exerting some pressure on tariff negotiations. In a region with several currencies, the nominal and real exchange rate corrects for some of the effects of that type of idiosyncratic shock. However, in a monetary union, this balancing mechanism does not exist, and the responses might turn into a downward competition of wages and wage costs. So it is of interest to ask whether wage formation is more symmetric or asymmetric in the Euro area. If shocks will be symmetrically distributed across the regions, symmetrical policy responses (= no policy option) will suffice. But, there were an argument for asymmetric policy responses, if shocks would be asymmetrically distributed. Asymmetric policy responses include a downward competition of wages, which we consider to be one of the most destabilizing perspectives of the Euro area.

Our study is related to the theory of the optimum currency area (OCA), but has a focus on the issue whether the conditions of an OCA are endogenous to a common currency and single monetary policy. Our approach is different to a strand of the literature, which tries to distinguish between long-run convergence and short-run deviations in unit labor costs (see recently: Deutsche Bundesbank 2007; Fischer 2007; Dullien and Fritzsche 2007). Convergence models are related to growth theory and the underlying real econo-

1 The authors gratefully acknowledge the comments made by Stefano Schiavo (Trento), Axel Lindner and Ingmar Kumpann (Halle), and Zorica Mladenovic (Belgrade). Special thanks go to Simone Lösel, who provided excellent research assistance. 
my fundamentals that drive convergence, while the dynamics of an OCA is driven by monetary factors. Also, we do not follow microeconomic and institutional approaches, which try to model the impact of a common currency on (absolute) flexibility in wage formation and labor market institutions on a single national labor market (see, for example Soscice and Iversen 2000; Calmfors 2001; Traxler 2002; Holden 2003; Mongelli and Vega 2006; Andersen and Seneca 2008). Our study has a macroeconomic approach and asks for relative flexibility in inter-regional relations.

For the European Union, the hypothesis of endogenous OCA criteria has been tested in many studies, but these studies excluded the labor market. Insofar, our study sets foot on a new territory. The political relevance is striking: if an asymmetric distribution of labor cost shocks would prevail or increase, the need for national political action would emerge in order to compensate for an imbalanced distribution of wage shocks. Our test for endogenous EU labor markets is based upon two components: Firstly, we investigate bilateral correlation coefficients with respect to synchronization of wage dynamics. Secondly, we test whether synchronization/de-synchronization is endogenous to the EMU. In this model, trade integration, financial market integration and different structures in production serve as explanatory variables and are assumed to be influenced by the common currency.

The study is organized as follows: The second section asks what we can learn from the relevant theoretical and empirical literature on OCA for our labor market analysis, and where are the open questions. The third section presents the variables of our model, describes how they are calculated, and which data source we exploited. The fourth section provides an overview on the calculated correlation coefficients of wage dynamics, after, and delivers the descriptive statistics for the dependent variable in our regression model. The latter plays an important role for the precise specification of the regression models. The fifth section presents the modeling for regressions and the results. The final section concludes. We find evidence for a persistent asymmetry in nominal wage formation with detrimental implications for the synchronization of unit labor cost dynamics and for balanced trade among EMU countries. 


\section{Theory and Empiricism of Endogenous Currency Area}

An OCA is characterized by a set of regions with integrated commodity, capital and labor markets, so that the structures of the regions are sufficiently similar. The conditions of optimality should be fulfilled if output/input movements ('migration') converge due to a high degree of commodity and input factor market integration. The theory of endogenous currency area states that quantitative adjustments, hence, factor and commodity mobility would be endogenous in the currency union, and asymmetric shocks would become symmetric ones over time. This statement is closely related to the Lucas critique (Lucas 1976), which means that a regime shift (in exchange rates or, a currency union) will change the behavior of agents.

But, there are few studies only that deal with the issue of endogenous labor markets in a single currency area. The neglect of labor markets is somewhat surprising since influential early contributions to the OCA literature (Meade 1957; Mundell 1961; Ingram 1973) discussed the labor market issue at a prominent place. The neglect of the labor market issue in the literature might be explained by the high costs of migration in the EMU compared, for example, to the US. Among the few studies, Mann-Quirici (2005) estimated a wage function for the United States with various monetary policy regimes since 1900. He argued, that an increase of the coefficients of the unemployment rate and output dynamics is seen as evidence for endogenous labor market responses. Silva (2005) measures endogeneity in the Euro area, applying a convergence regression and standard deviations and found no synchronization of wage. The model we are going to test roots in another strand of the literature. We argue that commodity and financial flows as well as specialization patterns and their possible changes might substitute for lacking crossborder labor mobility and might lead to a more or less symmetric adjustment of wage dynamics. If so, we might conclude that less symmetric adjustment is responsible for divergent wage and labor cost developments in the Euro area. Our model takes the general form of

$$
C_{i, j, \tau}=C\left(T_{i, j, \tau}, S_{i, j, \tau}(F), F_{i, j, \tau}\right)
$$

with $C_{i, j, \tau}$ as an indicator for synchronization of any type of macroeconomic aggregate changes (output, prices, wages) in a bilateral context of a country $i$ and a country $j$ over the period $\tau, T$ stands for the bilateral trade intensity. $S$ is the specialization variable, which is a function of financial integration, and $F$ ist the financial integration variable, which may impact indirectly (via specialization) and/or direction on the dependent variable. This research approach merges two important advances in research:

In their seminal work, Bayoumi and Eichengreen (1993) provided a new methodology to disentangle short term shock disturbances on prices and output from long-run adjustments in a currency area. Since then, the measure of symmetric shock responses $C$ is the 
correlation coefficient of de-trended level aggregates, usually output. The authors compared US and European business cycles with respect to various demand and supply shocks and found (i) the US-regional framework to be more flexible than the European Union, and (ii) core European Union to be more flexible than periphery Union (Southern member countries). Authors became skeptical about the introduction of a common currency in the EU for all countries before the necessary pre-requisites were established. The single European currency might push the member countries into a more specialized economic structure, thereby magnifying the asymmetric nature of (demand) shocks (Basevi 1993). This was in line with Krugman (1993), who argued that regions should not form a common currency area if they differed largely in sector or product patterns (= large differences in per capita income).

Frankel and Rose (1998) argued that optimum conditions must not be fulfilled ex-ante but emerge ex-post under the influence of the common currency and single monetary policy. They tested an empirical model with the correlation coefficient of de-trended dynamics of economic activity (GDP, industrial output, employment, unemployment) as dependent variable, and trade intensity $T$ as explanatory variable for OECD countries. Both variables are endogenous in a currency area. The common currency and single monetary policy reduce transactions costs in trade, increase the bilateral flows of commodities and synchronizes the business cycles of the involved regions. Hence, trade intensity stands for quantitative adjustment of commodity markets, and changes in intensity for changes in the speed of adjustment. To obtain a clear picture of the dynamics, they performed the tests for several periods of European integration. The coefficient to the trade variable should be positive in regressions, if the regions form a currency union or, at least, cooperate closely in monetary policy. Then, quantitative adjustments should gain momentum. Further, a positive coefficient would reflect the absence of industryspecific shocks, prevalent in case of inter-industry specialization (reflecting Krugman's 1993 specialization hypothesis). In sum: what they, and many studies of later authors did (for an overview, see de Haan et al., 2008), is to estimate whether and how the speed of quantitative adjustment (higher commodity market integration) overwhelms asymmetric price disturbances over time - while Bayoumi and Eichengreen's approach tried to measure the impact of shocks on output co-movements, while quantitative adjustments are exogenous. Frankel and Rose found the expected positive signs for trade intensity for periods prior to 1998 in regressions with instruments (instruments clear the trade intensity variable for exogenous determinants like distance, common border and language).

In this study, we transfer the trade intensity argument to the labor market: The higher the intensity of trade in similar products, the more present is the labor costs of country $i$ in the wage formation process in country $j$. Hence, the 'quantitative' adjustment happens in labor market flexibility adjustments inside the regions. If so, we predict a positive sign of the coefficient in regressions. This is Hypothesis 1 (H 1), we are going to test. Further, we add financial integration and specialization patterns as variable to trade intensi- 
ty, and here, we follow recent studies on output synchronization (Imbs 2004; Schiavo 2005). On the one side, specialization patterns decide over the transmission of industryspecific shocks. With high specialization, one would rather expect a de-synchronization of output (as well as wage dynamics). On the other side, specialization is endogenous in the currency area, too, and it is affected by financial integration, which certainly belongs to mostly endogenous variables. In fact, the literature concentrates on an indirect link through specialization; this is the reason why in Equation (1) $S$ is described as being a function of $F$. Remember that specialization is relevant for the effect of increasing trade intensity on the synchronization measure. This hypothesis roots in a strand of literature (see Kalemli-Oczan et al. 2003 with further references), which states that more risk sharing through an increased trade in assets acts like the lifting of trade barriers: countries can specialize their production according to their comparative advantages. Hence, more financial integration leads via more specialization to a de-synchronization of output cycles or, as we assume, of wage dynamics via industry-specific shocks. This is our second hypothesis ( $\mathrm{H}$ 2) we will test. Two relevant issues emerge: firstly, the hypothesis roots in the classical theory of trade. With more intra-industry trade, the assumed relation should not show up in regressions. Secondly, apart from the way through specialization, we may not exclude a direct link between financial integration and the synchronization of macroeconomic dynamics. Assume financial integration to propagate the aims of a common macroeconomic policy to a set of countries with formerly divergent monetary conditions; formerly divergent inflation rates start to converge. This is the third hypothesis ( $\mathrm{H} 3$ ) for testing in this study. If the predicted sign in regressions with financial integration appears, the correlation of wage dynamics should reflect the inclusion of the common inflation rate into national price or wage functions, and hence, stand for more synchronization. A schematic presentation of the links discussed and hypothesis to test is given in Figure 1. 
Figure 1:

The interplay between the common currency and wage dynamics

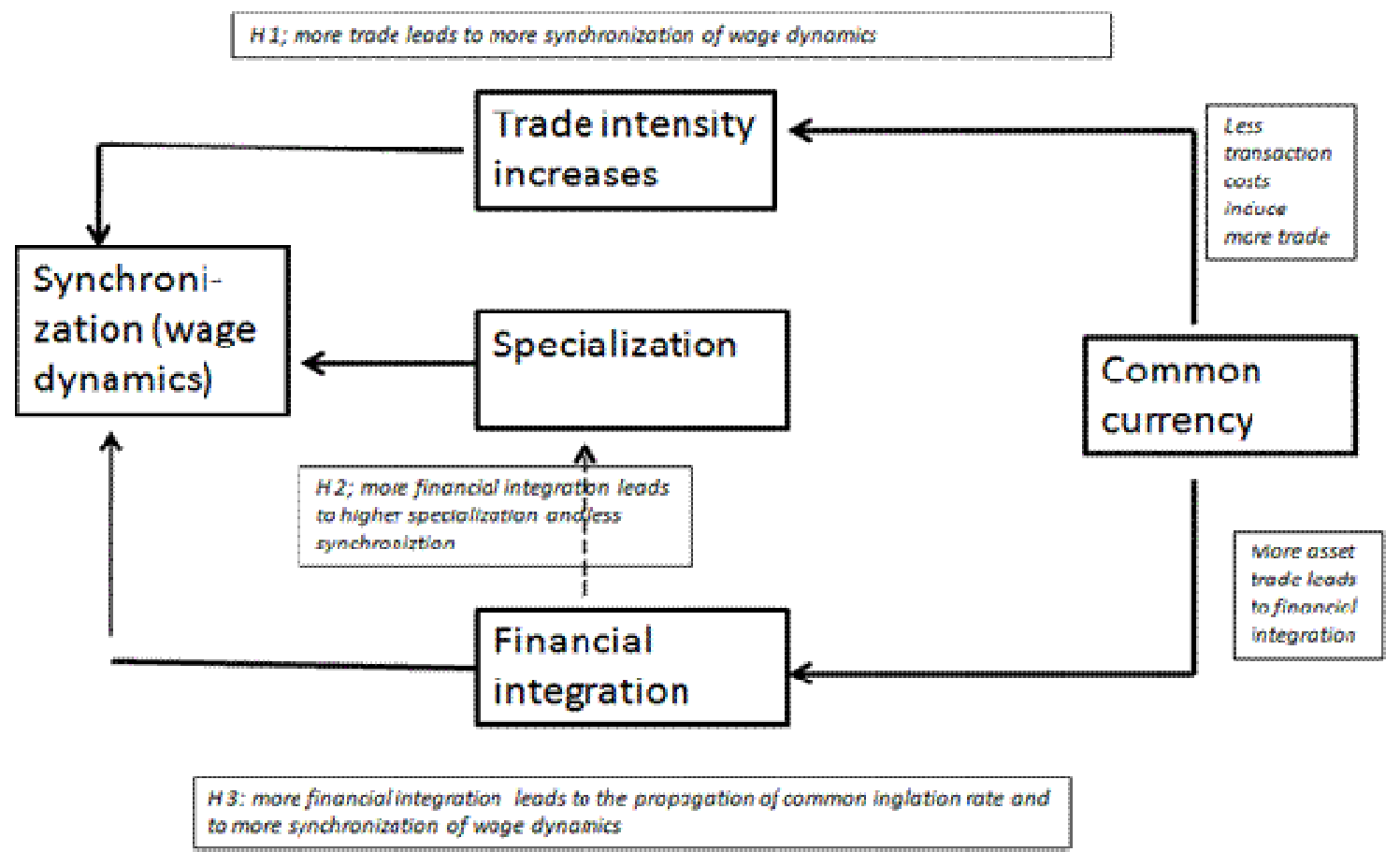

Source: IWH 


\section{Data and Calculation of Variables}

We investigate bilateral correlation coefficients of labor cost dynamics between 1980 and 2007. We divide the period into three sub-periods in order to find meaningful results with respect to the various currency regime events and shifts. The first period includes the years 1981-1989 (European Monetary System with an exchange rate band of $\pm 2.5 \%$ ). The second period runs from 1990 until 1997 (including the EMS crisis 19921993 , the relaxation of the band width to $\pm 15 \%$, and preparations of countries to fulfilling the convergence criteria). The third period includes the first ten years of the Euro currency and of a common monetary policy, starting with 1998 (fixing of exchange rates). Insofar, our approach is different to other work that uses dummies for fixed exchange rates (Frankel and Rose 1998), or EMU membership (Schiavo 2005). Periodaverage coefficients include information about lagged reactions of a country's wage formation to a shock from the partner country. We receive 55 bilateral country-pair observations per period for 11 countries (except Luxembourg): $11 * 11=121,(121-11) / 2$.

Correlation coefficients are calculated from Ameco data series base according to three concepts: nominal compensation per employee (NCE) in Euro; real compensation per employee (RCE) as index, which were transformed into Euro series, and unit labor costs (ULC), calculated as nominal wages over productivity. The nominal compensation per employee is not restricted to contractual wages, and includes social taxes (employers' contributions). Ameco calculates the number of employees in full-time equivalents, as far as possible; hence, they also include a good portion of part-time work and related employment models. The real compensation per employee is used to evaluate the impact of different inflation processes in the countries. We assure a similar movement of NCE and RCE, if nominal wage shocks cause a reaction in the price level. The Ameco data presents real indices calculated by the help of the GDP deflator. We took the log-levels and calculated the correlation coefficients according to two methods: (i) we took first differences and received the annual rates of changes; (ii) we applied the HP filter to obtain the cycle movements in the levels. The former coefficients are used for sensitivity checks. The coefficients serve for an inspection of the size and distribution over the three sub-periods.

We transformed level data series of labor costs into annual growth rates as well as detrended them by applying the HP-filter to the original series. Transformations are necessary for two reasons: first, to achieve stationary time series for each country and second, to concentrate largely on business cycle or short-term fluctuations in the series between the countries considered. Using two alternative measures - annual growth rates and HPfiltered data - is intended to serve as a robustness check with respect to the results obtained in the later steps. For regressions, we follow Otto et al. (2001), who argue that correlation coefficients might lead to distortions in regressions for they move in a nar- 
row frame of \pm 1 , while other variables move in the entire frame of real figures. Therefore, we use logistically transformed correlation coefficients according to

$$
c_{i j}=\ln \left(\frac{\rho_{i j}+1}{1-\rho_{i j}}\right)
$$

with $\rho_{i, j, \tau}$ as the original correlation coefficient. In these regressions, we test various variables, which are assumed to have an impact on correlation coefficients. All other variables enter regressions with their log-levels.

We calculate the bilateral trade intensity is according to three concepts, exports, imports and total trade:

Export intensity:

$$
T X_{i, j, \tau}=\frac{X_{i, j, \tau}}{X_{i, \tau}+X_{j, \tau}}
$$

Import intensity:

$$
T M_{i, j, \tau}=\frac{M_{i, j, \tau}}{M_{i, \tau}+M_{j, \tau}}
$$

Total trade intensity:

$$
T T_{i, j, \tau}=\frac{X_{i, j, \tau}+M_{i, j, \tau}}{\left(X_{i, j, \tau}+M_{j, \tau}\right)+\left(X_{j, i, \tau}+N_{j, i, \tau}\right)}
$$

The reason for the three concepts is that trade reporting in national statistics differed in the past, and even differs under the EU single market to a certain degree. Hence, exports of country $i$ to country $j$ are not necessarily the imports of country $j$ from country $i$. A positive sign in regressions confirms Hypothesis H1.

We calculated the specialization indicator on the basis of the employment shares of 26 sectors of the STAN data base of OECD as

$$
S_{i, j, \tau}=\sum_{k} \mid \text { share }_{i, k, \tau}-\text { share }_{j, k, \tau} \mid
$$

with $\mathrm{k}$ various sectors. A pair of countries has an identical industrial structure, if the variable takes the value 0 . Otherwise, the higher the value is, the larger are the differences in structure. If specialization matters, a formerly negative sign to trade intensity in regressions without specialization should turn into the positive in regressions with specia- 
lization, and the specialization variable should obtain a negative sign. This result would confirm Hypothesis H 2. Schiavo (2005) constructed an additional specialization indicator, calculating the Herfindahl index for each country and taking the product for each country pair. We restricted our approach to the indicator, which seems to be more transparent in its economic content.

Finally, we include financial market integration into the model. The financial integration variable is constructed as Euclidian distance:

$$
F_{i, j, \tau}=\sqrt{\left(l i r_{i, \tau}-l i r_{j, \tau}\right)^{2}+\left(s i r_{i, \tau}-s i r_{j, \tau}\right)^{2}}
$$

with lir and sir as the long-term (10 years T-bonds) and short-term interest rate (3months), respectively. Data were taken from the OECD Main Economic Outlook. A diminishing variable signals more financial market integration. Hence, the sign should become positive in regressions with specialization $(\mathrm{H} 2)$, and negative in regressions, if there is a direct link between specialization and wage dynamics. 


\section{An Overview on Correlation Coefficients and their Quality Signs}

This section provides the descriptive statistics for the dependent variable - the bilateral correlation coefficients. The data describe first impressions about the changes in wage dynamics synchronization and underlying statistical properties. Both will help to reveal problems, which will be incorporated into the regression models following in section five.

A simple count of positive and negative correlation coefficients (Table 1) shows for all observations (upper panel) that positive correlations prevailed in the first sub-period (1981-1989). The second sub-period reveals a drastic decline of positive correlations, which might be explained by the mixed character of that period. The third sub-period, which is influenced by the common currency, shows a restoration of positive correlations only for unit labor costs (ULC), but not for real and nominal compensation per employee (RCE and NCE). More, RCE and NCE positive correlations continued to decline, mainly in the number of significant correlations.

Table 1:

The distribution of signs of bilateral correlation coefficients ( 55 observations; HP filter)

\begin{tabular}{|c|c|c|c|c|c|c|c|c|c|}
\hline \multirow[b]{2}{*}{ Signs } & \multicolumn{3}{|c|}{$\Delta \log (\mathrm{RCE})$} & \multicolumn{3}{|c|}{$\Delta \log (\mathrm{NCE})$} & \multicolumn{3}{|c|}{$\Delta \log ($ ULC $)$} \\
\hline & $\begin{array}{r}1981- \\
1989\end{array}$ & $\begin{array}{c}1990- \\
1997\end{array}$ & $\begin{array}{l}1998- \\
2007\end{array}$ & $\begin{array}{l}1981- \\
1989\end{array}$ & $\begin{array}{c}1990- \\
1997\end{array}$ & $\begin{array}{l}1998- \\
2007\end{array}$ & $\begin{array}{c}1981- \\
1989\end{array}$ & $\begin{array}{c}1990- \\
1997\end{array}$ & $\begin{array}{l}1998- \\
2007\end{array}$ \\
\hline \multicolumn{10}{|l|}{ All observations } \\
\hline Positive & 40 & 27 & 25 & 38 & 30 & 28 & 40 & 31 & 36 \\
\hline$\ldots$ of which significant $t^{a}$ & 23 & 14 & 9 & 21 & 14 & 8 & 22 & 13 & 18 \\
\hline Negative & 15 & 28 & 30 & 17 & 25 & 27 & 15 & 24 & 19 \\
\hline$\ldots$ of which signifikant ${ }^{\mathrm{a}}$ & 2 & 12 & 12 & 2 & 12 & 11 & 1 & 15 & 4 \\
\hline \multicolumn{10}{|c|}{ (only observations with $\rho_{i, j, \tau}>|0,5|$ ) } \\
\hline Positive & 26 & 15 & 10 & 25 & 15 & 10 & 24 & 15 & 19 \\
\hline$\ldots$ of which significant ${ }^{a}$ & 23 & 14 & 9 & 21 & 14 & 8 & 22 & 13 & 18 \\
\hline Negative & 3 & 14 & 13 & 2 & 18 & 12 & 2 & 17 & 5 \\
\hline$\ldots$ of which significant ${ }^{a}$ & 2 & 12 & 12 & 2 & 12 & 11 & 1 & 15 & 4 \\
\hline
\end{tabular}

${ }^{a}$ Significant at a level of at least $10 \%$.

Source: Authors' calculation, based on Ameco data.

The lower panel of Table 1 includes only bilateral cases with a high correlation of $\left(\rho_{i, j, \tau}>|0,5|\right.$. The results mirror the picture of the upper panel. We checked these result against bilateral coefficient coefficients calculated with the annual growth rates and found somewhat different results with respect to the upper panel (Table 1 in the Appendix). Again, the second period presents a picture of declining positive coefficients, however, the third period a strong recovery. On the other side, significant high correlations 
repeat our findings with HP-de-trended data. In sum, we do not obtain a clear picture on the path synchronization of wage dynamics took in the entire period.

The descriptive statistics of the correlation coefficients reveals that for all variables the second sub-period from 1990 to 1997 comes up with lower means, wider ranges (maximum - minimum) and correspondingly with higher standard deviations than the two other sub-periods (Table 2). Furthermore, in two out of three cases the assumption that the data are normally distributed has to be rejected (JB statistics) at least at the five percent level of significance. A plot of the logistically transformed correlation coefficients (not in logs) shows that there are extreme outliers in the data which are in most cases related to the Netherlands and the corresponding bivariate correlations (Figure 2).

Table 2:

Descriptive statistics of the dependent variables (logistically transformed bilateral correlation coefficients, calculations are based on HP-filtered data) ${ }^{\mathrm{a}}$

\begin{tabular}{|l|c|c|c|c|c|c|}
\hline & Mean & Median & Maximum & Minimum & $\begin{array}{c}\text { Standard } \\
\text { deviation }\end{array}$ & JB-Statistic \\
\hline $\log (\mathrm{NCE})$ & 0.784 & 0.541 & 4.078 & -1.498 & 1.301 & 2.118 \\
$1980-1989$ & 0.759 & 0.437 & 3.668 & -1.498 & 1.229 & 1.397 \\
\hline $\log (\mathrm{NCE})$ & 0.254 & 0.237 & 6.418 & -4.292 & 2.390 & 0.941 \\
$1990-1997$ & 0.093 & 0.237 & 4.428 & -4.254 & 2.115 & 0.255 \\
\hline $\log (\mathrm{NCE})$ & -0.030 & 0.067 & 3.536 & -3.123 & 1.381 & 0.430 \\
$1998-2007$ & -0.171 & -0.038 & 3.006 & -3.123 & 1.232 & 0.070 \\
\hline $\log (\mathrm{RCE})$ & 0.963 & 0.942 & 3.858 & -2.205 & 1.448 & 0.825 \\
$1980-1989$ & 0.835 & 0.925 & 3.788 & -2.205 & 1.358 & 0.524 \\
\hline $\log (\mathrm{RCE})$ & 0.367 & -0.309 & 5.838 & -2.777 & 2.400 & $6.256^{* *}$ \\
$1990-1997$ & 0.201 & -0.309 & 5.838 & -2.689 & 2.173 & $6.695^{* *}$ \\
\hline $\log (\mathrm{RCE})$ & 0.037 & -0.086 & 4.102 & -2.123 & 1.300 & 4.428 \\
$1998-2007$ & -0.033 & -0.049 & 2.650 & -2.123 & 1.118 & 1.146 \\
\hline $\log (\mathrm{ULC})$ & 0.847 & 0.824 & 3.605 & -1.602 & 1.238 & 1.447 \\
$1980-1989$ & 0.861 & 0.861 & 3.274 & -1.602 & 1.238 & 1.633 \\
\hline $\log (\mathrm{ULC})$ & 0.474 & 0.062 & 5.980 & -2.427 & 2.197 & $6.315^{* *}$ \\
$1990-1997$ & 0.247 & 0.034 & 5.233 & -2.427 & 1.935 & $5.218^{* * *}$ \\
\hline $\log (\mathrm{ULC})$ & 0.589 & 0.517 & 3.414 & -1.670 & 1.303 & 1.794 \\
$1998-2007$ & 0.449 & 0.485 & 2.688 & -1.670 & 1.168 & 1.527 \\
\hline
\end{tabular}

${ }^{\text {a }}$ Bivariate correlations of transformed correlation coefficients based on annual growth rates (the exercise with HP filter coefficients produced similar results) ${ }^{* * *},(* *),(*)$ indicates significance at the $1 \%,(5 \%),(10 \%)$ level. Cursive figures are related to the dataset with Netherlands excluded.

Source: Own calculations. 
Figure 2:

Plot of bivariate correlation coefficients using three wage measures (HP-filtered data)

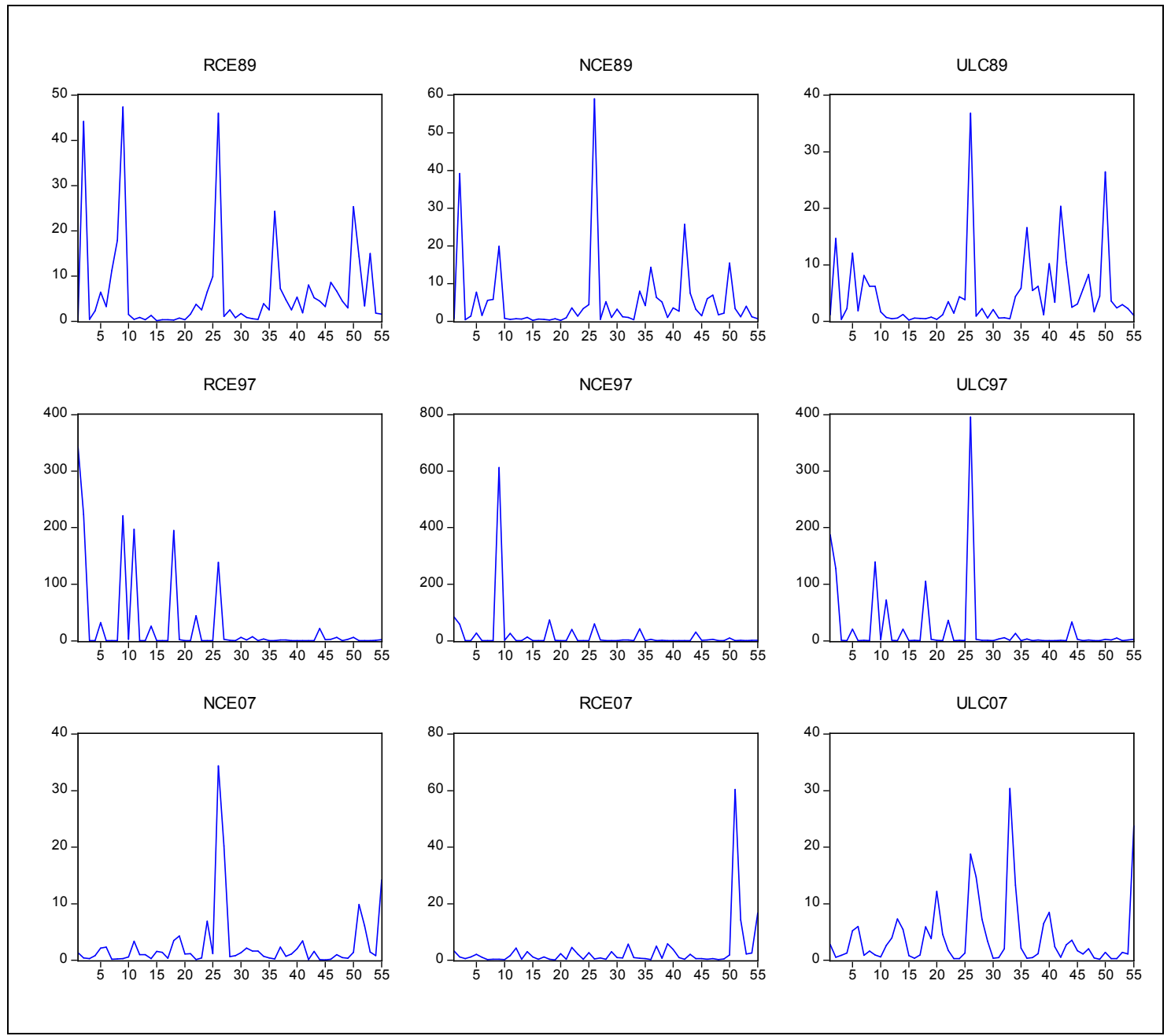

Source: Own calculation.

Compared with the other data, NCE97 (second sub-period) shows that there is a large outlier in the series, being six times larger than the other values. And even more pronounced is the picture for ULC97. In most of these cases we are concerned with a transformed correlation coefficient between the Netherlands and another country. Taking logs of the data of course dampens the effects of outliers, but the problem is only less pronounced instead of solved. In lack of a convincing explanation of this fact, we might estimate our equations with the Netherlands included in the dataset as well as with the Netherlands excluded, which results in a loss of ten observations for each sub-period. Another option is the use of a specific dummy for all bilateral observations with the Netherlands.

Table 3: 
Correlation matrix of the dependent variable sets (all variables are in logs) ${ }^{2}$

\begin{tabular}{|c|c|c|c|c|c|c|c|c|c|}
\hline & $\begin{array}{c}\mathrm{NCE} \\
1980-89 \\
\end{array}$ & $\begin{array}{c}\text { NCE } \\
1990-97 \\
\end{array}$ & $\begin{array}{c}\text { NCE } \\
1998-07 \\
\end{array}$ & $\begin{array}{c}\text { RCE } \\
1980-89 \\
\end{array}$ & $\begin{array}{c}\text { RCE } \\
1990-97\end{array}$ & $\begin{array}{c}\text { RCE } \\
1998-07\end{array}$ & $\begin{array}{c}\text { ULC } \\
1980-89\end{array}$ & $\begin{array}{c}\text { ULC } \\
1990-97\end{array}$ & $\begin{array}{c}\text { ULC } \\
1998-07\end{array}$ \\
\hline $\begin{array}{l}\text { NCE } \\
1980-89\end{array}$ & - & .227 & -.014 & $.899 * * *$ & .073 & -.028 & $.900 * * *$ & .134 & -.043 \\
\hline $\begin{array}{l}\text { NCE } \\
1990-97\end{array}$ & $.320 * *$ & - & .058 & .150 & $.772 * * *$ & .127 & .197 & $.895 * * *$ & .140 \\
\hline $\begin{array}{l}\text { NCE } \\
1998-07\end{array}$ & .023 & .021 & - & -.169 & .096 & .095 & -.157 & .014 & $.329 * *$ \\
\hline $\begin{array}{l}\mathrm{RCE} \\
1980-89\end{array}$ & $.892 * * *$ & .201 & -.120 & - & -.014 & .046 & $.904 * * *$ & .057 & -.177 \\
\hline $\begin{array}{l}\mathrm{RCE} \\
1990-97\end{array}$ & .194 & $.822 * * *$ & .078 & .060 & - & .229 & .059 & $.847^{* * *}$ & .212 \\
\hline $\begin{array}{l}\text { RCE } \\
1998-07\end{array}$ & -.123 & -.081 & .103 & .029 & -.042 & - & -.034 & .120 & .202 \\
\hline $\begin{array}{l}\text { ULC } \\
1980-89\end{array}$ & $.919 * * *$ & $.243 *$ & -.055 & $.883 * * *$ & .138 & -.092 & - & .093 & -.038 \\
\hline $\begin{array}{l}\text { ULC } \\
1990-97\end{array}$ & $.298 * *$ & $.904 * * *$ & .055 & .188 & $.874 * * *$ & -.095 & $.226^{*}$ & - & .186 \\
\hline $\begin{array}{l}\text { ULC } \\
1998-07\end{array}$ & -.010 & .220 & $.376^{* * * *}$ & -.189 & $.281 * *$ & .035 & -.010 & $.252 *$ & - \\
\hline
\end{tabular}

Recursive figures (upper right part of the matrix) relate to the correlations with The Netherlands excluded, in the lower part of the table the Netherlands are included. $*{ }^{* *}, * * *$ means significant at the $10 \%, 5 \%, 1 \%$ level. The table reveals the results for the data in annual growth rates. Results for HP-filtered data do not show a different pattern and are available from the authors upon request.

Source: Own calculation.

Finally, we are interested to find out (a) whether the dependent variables RCE, NCE and ULC are correlated to each other for a given period, and (b) between periods. We obtain information about the robustness of regression results with one of the wage concepts are, and information about the appropriateness of our sub-period definitions. Bivariate correlation coefficients were calculated including and excluding the Netherlands. The upper right part of Table 3 reports data including the Netherlands, and the lower left part excluding the Netherlands. Out of the 36 bivariate correlations in the upper right part, only seven coefficients are statistically different from zero. And in all of these seven cases, the correlations are significant between the different labor market variables, hence, NCE (1980-89) is correlated with RCE and ULC of the same period at a 1\% level of significance. The same holds more or less for the other two sub-periods. Hence, we may expect regressions to yield similar results for all three concepts of wages. Further, there is no correlation between NCE (RCE, ULC) of a certain period and the same variable of the other two sub-periods. This perhaps may be interpreted as a first indication that the data in the three sub-periods exhibit completely different behavioral patterns, and we may conclude that we defined the sub-periods appropriately.

2 Detailed descriptive data analyses for the HP-filtered dataset are available from the authors upon request. 


\section{Estimating and Testing Different Hypotheses on Labor Cost Behavior and Trade}

In regressions the Hodrick-Prescott-filtered (HP-filtered) logs of the data are used. This is a common way to achieve stationarity whereas annual growth rates are always a combination of cyclical movements (due to business cycle developments and additional random effects) and of the secular growth path of the economy. The first differences of the logs of the data series are used for robustness checks and reported at the end of this section.

We decided to prefer a panel structure of the data against a cross-section approach, since the panel structure allows for using cross-section weights in regressions. Cross-section weights seem to be important, for we work with very different country pairs (for example, German-Greece, France-Italy). All the estimation results we present in the set of Tables hereafter include the Netherlands. Regressions without country-pairs with the Netherlands were used for robustness tests, and their results are reported in the appendix.

We start with testing Hypothesis $\mathrm{H}$ 1, i.e., more trade leads to more synchronization of wage dynamics, estimating bivariate regressions with Instrument Variables (IV). IV serves to clear trade intensity from exogenous influences. We used lagged values of the explanatory variables as instruments and the distance measure as well as a dummy variable indicating a joint border or not (known from gravity approaches to trade). The results are displayed in Table 1. Estimation results confirm $\mathrm{H} 1$ for RCE and ULC, but not for NCE with respect to the euro area sub-period of 1998-2007 (Table 1). While for RCE and ULC the impact of trade intensity on wage dynamics is positive and statistically significant from zero at the $1 \%$ level, the impact on NCE changed from a positive to a negative sign between the two sub-periods considered. But the impact is considerably higher in the period 1990 to 1997 than in the last period ranging from 1998 to 2007. Furthermore, export intensity seems to perform better than the other two selected measures of trade intensity, imports or total trade. Comparable results are obtained if total trade is used instead of exports. But for the import variable we obtain mixed results, especially if emphasis is put on ULC. OLS estimations (see Table A2 in the appendix) yield a similar result with minor deviations on regressions with import intensity. But here, we find a change of a minus sign in the first sub-period of 1980-1989 to a positive sign in the subsequent periods for exports and total trade. Hence, we assume the confirmation of $\mathrm{H} 1$ as robust. We explain the different results for nominal and real wage dynamics with inflation differentials between the countries, which are relevant for nominal wage formation, but not for real wage formation: nominal wage formation seems to be linked to inflation. Below, we will try to find out whether it is national inflation or rather Euro area inflation. With respect to ULC we might conclude that a higher trade intensity contributes to the transfer of productivity achievements from one country to the other, 
and nominal wage formation does not only reflect the inflation rate but also productivity progress (assuming the usual wage function approach).

Table 4:

Instrumental variable estimates of relationships between selected wage variables and trade intensity measures, $\mathrm{N}=55$, HP-filtered data

\begin{tabular}{|l|r|r|r|r|r|r|}
\hline & \multicolumn{2}{|c|}{ HP_Log(RCE) } & \multicolumn{2}{c|}{ HP_Log(NCE) } & \multicolumn{2}{c|}{ HP_Log(ULC) } \\
\cline { 2 - 7 } & $1990-1997$ & $1998-2007$ & $1990-1997$ & $1998-2007$ & $1990-1997$ & $1998-2007$ \\
\hline $\log (\mathrm{x})$ & $0.551^{* * *}$ & $0.380^{* * *}$ & $0.634^{* * *}$ & $0.073^{* * *}$ & $0.602^{* * *}$ & $0.434^{* * *}$ \\
\hline Adj. $R 2$ & 0.577 & 0.773 & 0.945 & 0.302 & 0.511 & 0.797 \\
\hline & & & & & & \\
\hline $\log (\mathrm{m})$ & $0.774^{* * *}$ & $0.087^{* * *}$ & $0.721^{* * *}$ & $-0.102^{* * *}$ & $0.930^{* * *}$ & $0.357^{* * *}$ \\
\hline Adj. $R 2$ & 0.997 & 0.298 & 0.763 & 0.279 & 0.962 & 0.891 \\
\hline & & & & & & \\
\hline $\log (\mathrm{tt})$ & $0.739 * * *$ & $0.247^{* * *}$ & $0.793^{* * *}$ & -0.004 & $0.914^{* * *}$ & $0.478^{* * *}$ \\
\hline Adj. $R 2$ & 0.683 & 0.823 & 0.812 & 0.000 & 0.733 & 0.769 \\
\hline
\end{tabular}

Constant term is not reported. For a definition of the variables see appendix. $\mathrm{N}=55$ cross section units. ${ }^{* * *},\left({ }^{* *}\right),\left({ }^{*}\right)$ $=$ significant at the $1 \%,(5 \%),(10 \%)$ level. Instruments: the distance measure and the dummy variable indicating a joint border or not, the dummy for the Netherlands, constant term., one period lagged explanatory variable.

Source: Own calculation.

Testing Hypothesis H 2 - financial integration affects the synchronization of wage dynamics indirectly via changes in the sectoral specialization patterns - we, firstly, estimate the relationship between financial integration and sectoral specialization, and find H 2 to be confirmed so far (Table 4). The regression coefficients are positive and significant at the $1 \%$ level for all three sub-periods, and the adjusted $\mathrm{R}^{2} \mathrm{~s}$ report a high explanatory power of this relationship. The results are robust, regardless whether we applied OLS or IV estimations. 
Table 5:

Estimates of the impact of financial integration on sector specialization

\begin{tabular}{|l|l|l|c|c|l|}
\hline & Constant & $\log (\mathrm{FI})$ & R2(adj.) & \multicolumn{1}{|c|}{ Period } & \multicolumn{1}{|c|}{ Instruments } \\
\hline 1 & $3.782 * * *$ & $0.078 * * *$ & 0.826 & $1980-1989$ & OLS \\
\hline 2 & $3.568 * * *$ & $0.140 * * *$ & 0.797 & $1990-1997$ & OLS \\
\hline 3 & $3.591 * * *$ & $0.120 * * *$ & 0.868 & $1990-1997$ & IV: const, log(FI(-1)) \\
\hline 4 & $3.568 * * *$ & $0.132 * * *$ & 0.976 & $1990-1997$ & $\begin{array}{l}\text { IV: const, log(FI(-1)), joint } \\
\text { border, log(distance) }\end{array}$ \\
\hline 5 & $3.650 * * *$ & $0.059 * * *$ & 0.746 & $1998-2007$ & OLS \\
\hline 6 & $3.772 * * *$ & $0.139 * * *$ & 0.942 & $1998-2007$ & IV: const, log(FI(-1)) \\
\hline 7 & $3.782 * * *$ & $0.144 * * *$ & 0.812 & $1998-2007$ & $\begin{array}{l}\text { IV: const, } \log (\mathrm{FI}(-1)), \text { joint } \\
\text { border, } \log (\operatorname{distance})\end{array}$ \\
\hline
\end{tabular}

$* * *=$ significant at the $1 \%$ level; OLS $=$ ordinary least squares regression; IV = instrument variable estimation. Estimation with cross section weights.

Source: Own calculation.

Finally, we test Hypotheses H 2 (the 'second' step) and H 3 in a combined procedure with instrument variables, and relate wage dynamics in real and nominal terms to all three variables (trade intensity, specialization, and financial integration). With respect to the dynamics of real wages (RCE), Table 6 shows that all trade variables confirm the results already obtained in $\mathrm{H} 1$ regressions (Table 4). Specialization, however, yields a somewhat surprising result: the unique picture is that the regression coefficient takes a positive sign, with the variable being significant in most cases. Confirming $\mathrm{H} 2$, however, would require a negative sign in regressions (due to the construction of the specialization variable). Differently said, performing the second step of testing H 2, namely relating specialization to real wage dynamics, leads not to the confirmation of $\mathrm{H} 2$, although the first step revealed a strong impact of financial integration on specialization. Hence, industry or sector specific shocks do not play an important role for the synchronization or de-synchronization of real wage dynamics. With respect to $\mathrm{H} 3$, we find the expected negative sign (more financial integration $=$ less interest rate differentials, leads to more wage dynamics synchronization) for RCE in both sub-periods, significant at a level of $1 \%$, however, with declining regression coefficients. 
Table 6:

Cross section estimates of real wages, IV estimates

\begin{tabular}{|l|r|r|r|r|r|r|}
\hline & \multicolumn{7}{|c|}{ Dependent variable: HP_Log(RCE) } \\
\cline { 2 - 7 } & $1990-1997$ & \multicolumn{1}{|c|}{$1998-2007$} & $1990-1997$ & $1998-2007$ & $1990-1997$ & $1998-2007$ \\
\hline Constant & -2.321 & $-8.390^{* * *}$ & $-5.116^{* * *}$ & $-6.779 *$ & $-3.338^{* *}$ & -12.256 \\
\hline $\log (\mathrm{x})$ & $0.674 * * *$ & $0.322^{* * *}$ & & & & \\
\hline $\log (\mathrm{m})$ & & & $0.569^{* * *}$ & $0.171^{*}$ & & \\
\hline $\log (\mathrm{tt})$ & & & & & $0.663 * * *$ & $0.329 * *$ \\
\hline $\log (\mathrm{sp})$ & $1.910^{* * *}$ & $2.657^{* * *}$ & $2.582^{* * *}$ & $2.063 * *$ & $2.179^{* * *}$ & 3.746 \\
\hline $\log (\mathrm{fi})$ & $-1.007 * * *$ & $-0.293^{* * *}$ & $-1.206^{* * *}$ & -0.241 & $-1.104 * * *$ & -0.350 \\
\hline R2 adj. & 0.889 & 0.629 & 0.967 & 0.688 & 0.913 & 0.119 \\
\hline Nobs & 55 & 55 & 55 & 55 & 55 & 55 \\
\hline
\end{tabular}

For a definition of the variables see appendix. $\mathrm{N}=55$ cross section units. Least squares estimates with cross-section weights. ${ }^{* * *},(* *),(*)=$ significant at the $1 \%,(5 \%),(10 \%)$ level. Instruments: $\log ($ distance $)$, common border, 1 period lagged $\log (\mathrm{sp}), 1$-period lagged $\log (\mathrm{fi})$, constant.

Source: Own calculation.

With respect to nominal wage dynamics (NCE), we obtain similar results for the trade intensity concepts (NCE negative in the third sub-period). However, there is not a clear pattern of impacts due to specialization and financial integration over time. We find a negative sign for specialization in the Euro sub-period, that means less specialization leads to more nominal wage synchronization, or differently said: industry specific shocks have an impact on nominal wages; hence, a confirmation of $\mathrm{H} 2$. The size of the positive regression coefficients is remarkable. With respect to financial integration, we find a turn from a minus to a positive sign both sub-periods compared (but, the variable is significant only in conjunction with exports and imports, but not with total trade). H 3 is not confirmed for nominal wage dynamics. Nominal wage formation in individual EMU countries does not seem to consider the common macroeconomic policy, reflected in an average inflation rate for the entire area. This result helps to explain our earlier finding, where trade intensity had not the expected sign on nominal wage dynamics (Table 1), which we explained with the relevance of country inflation in wage functions.

Regressions with unit labor costs (ULC) yield similar results for the trade intensity variables (confirming $\mathrm{H} 1$ for exports and total trade in the Euro sub-period), but no clear picture for the specialization variable. Hence, we cannot confirm H 2. Financial integration is no longer significant in the third sub-period, compared to the pre-Euro area period, when financial integration significantly contributed to more ULC synchronization. 
Table 7:

Cross section estimates of nominal wage per employee (log(nce)), IV estimates

\begin{tabular}{|l|r|r|r|r|r|r|}
\hline \multirow{2}{*}{} & \multicolumn{7}{|c|}{ Dependent variable: HP_Log(NCE) } \\
\cline { 2 - 7 } & $1990-1997$ & $1998-2007$ & $1990-1997$ & $1998-2007$ & $1990-1997$ & $1998-2007$ \\
\hline Constant & 0.985 & $11.216^{* * *}$ & 0.088 & $5.090^{* * *}$ & 0.779 & $5.860 * *$ \\
\hline $\log (\mathrm{x})$ & $0.607 * * *$ & $-0.331 * * *$ & & & & \\
\hline $\log (\mathrm{m})$ & & & $0.796^{* * *}$ & $-0.160^{* * *}$ & & \\
\hline $\log (\mathrm{tt})$ & & & & & $0.652^{* * *}$ & $-0.219^{* * *}$ \\
\hline $\log (\mathrm{sp})$ & $0.969 * * *$ & $-3.472^{* * *}$ & $1.420^{* * *}$ & $-1.596^{* * *}$ & $1.063^{* * *}$ & $-1.893 * * *$ \\
\hline $\log (\mathrm{fi})$ & $-1.161^{* * *}$ & $0.294 * * *$ & $-1.043^{* * *}$ & $0.152^{* * *}$ & $-1.144^{* * *}$ & $0.144^{* * *}$ \\
\hline R2 adj. & 0.991 & 0.508 & 0.939 & 0.996 & 0.982 & 0.402 \\
\hline Nobs & 55 & 55 & 55 & 55 & 55 & 55 \\
\hline
\end{tabular}

For a definition of the variables see appendix. $\mathrm{N}=55$ cross section units. Least squares estimates with cross-section weights. $* * *,(* *),(*)=$ significant at the $1 \%,(5 \%),(10 \%)$ level. Instruments: $\log ($ distance $)$, joint border, 1 -period lagged $\log (\mathrm{sp}), 1$-period lagged $\log (\mathrm{fi})$, constant.

Source: Own calculation.

Table 8:

Cross section estimates of unit labor costs $(\log (\mathrm{ulc}))$, IV estimates

\begin{tabular}{|l|r|r|r|r|r|r|}
\hline \multirow{2}{*}{} & \multicolumn{7}{|c|}{ Dependent variable: HP_Log(ULC) } \\
\cline { 2 - 7 } & $1990-1997$ & $1998-2007$ & $1990-1997$ & $1998-2007$ & $1990-1997^{\mathrm{a}}$ & $1998-2007^{\mathrm{a}}$ \\
\hline Constant & 0.234 & $-7.466^{* * *}$ & $-1.243^{*}$ & -0.091 & -0.669 & $-5.603 * * *$ \\
\hline $\log (\mathrm{x})$ & $0.751 * * *$ & $0.725 * * *$ & & & & \\
\hline $\log (\mathrm{m})$ & & & $0.893 * * *$ & $0.427 * * *$ & & \\
\hline $\log (\mathrm{tt})$ & & & & & $0.940^{* * *}$ & $0.635^{* * *}$ \\
\hline $\log (\mathrm{sp})$ & $1.511^{* * *}$ & $3.000^{* * *}$ & $1.984 * * *$ & 0.719 & $1.920^{* * *}$ & $2.456^{* * *}$ \\
\hline $\log (\mathrm{fi})$ & $-1.407 * * *$ & $-0.447 * * *$ & $-1.120^{* * *}$ & -0.072 & $-1.273 * * *$ & $-0.241^{* * *}$ \\
\hline R2 adj. & 0.877 & 0.934 & 0.998 & 0.795 & 0.892 & 0.801 \\
\hline Nobs & 55 & 55 & 55 & 55 & 55 & 55 \\
\hline
\end{tabular}

For a definition of the variables see appendix. $\mathrm{N}=55$ cross section units. Least squares estimates with cross-section weights. $^{* * *},(* *),(*)=$ significant at the $1 \%,(5 \%),(10 \%)$ level. Instruments: $\log ($ distance), joint border, 1 -period lagged $\log (\mathrm{sp})$, 1-period lagged $\log (\mathrm{fi})$, constant. a) as additional instrument $\log (\operatorname{tt}(-1))$ has been used.

Source: Own calculations.

As mentioned in Section 4, the Netherlands should be considered as outlier in the sample. Therefore, we re-estimated the wage and unit labor cost equations with the Netherlands excluded. The detailed results can be found in the appendix under Tables A3, A4, and A5, corresponding to Tables 6, 7 and 8 above. With respect to the real wage variable, RCE, the results without the Netherlands are very similar to those reported in the text. All signs of the coefficients are the same, and all coefficient estimates declared as 
significant with the Netherlands included also remain significant without the Dutch data. With respect to nominal wage dynamics both tables (Table 7 and A4) differ somewhat more in the results, but the overall impression remains the same, namely financial integration switches in sign across periods and across different trade specifications, and that the trade variables show a negative sign in the last sub-period. And finally, with respect to the unit labor costs, ULC, the results are slightly better with the Netherlands excluded from a purely statistical point of view. Especially the impact of financial integration, FI, is significant in five out of six regressions without the Netherlands and shows the expected negative sign, whereas FI is significant only in the period from 1990 to 1997 in the case the Netherlands are included.

A couple of additional regressions were estimated to test the results for robustness. The first approach is to check whether estimations with first differences yield similar results. Tables in Appendix B present results of all the regressions in the main part. Table B4 (compare to Table 4) depicts the impact of the trade measures on wages and unit labour costs. Most results remain unchanged in their signs as well as in their statistical significance. Furthermore, the impact is again higher in the second period than in the third period. Also, similar results are obtained for the basic regressions with the trade, specialization, and financial integration variables (compare Table 6, 7, and 8 and B6, B7, B8). The results for real compensation per employee as well as for unit labour costs appear even more robust than those obtained for the nominal wage variable. The sign of the financial integration variable changes its sign across the periods when nominal compensation is the endogenous variables, whereas the signs are similar in most cases for the two alternative measures. It should be noted that the import variable performs considerably worse compared with the export intensity or total trade intensity.

The second approach is to ask for the impact of the outliers in the data set, in particular clustered around the Netherlands. Results given in appendices C and D either drop the Netherlands pairs from the sample, leaving a total of 45 observations, or introduce a dummy variable to account for the Netherlands case. Comparing the results with the appropriate tables in the main part, we found results not changed too much, with respect to the use of first differences as well as for the special treatment of the Netherlands. We conclude outliers do not lead to a major distortion of our main findings. Finally, we completed these exercises by repeating the tests C and D (first differences) with HP filtered data. The results are reported in the appendices $\mathrm{E}$ and $\mathrm{F}$. We did not find any major deviation from results with first differences in appendices $C$ and D and, hence, with HP filtered data in our basis regressions. 


\section{Conclusion}

We intended to find out how endogenous labor markets in the EMU are by measuring their synchronization with wage dynamics. We tested three hypotheses, and found rather clear evidence for an impact of trade intensity on the synchronization of real wage and unit labor costs dynamics. With respect to real wages, our result is backed by earlier studies, which explain the synchronization of economic activities by increasing trade intensity in a currency area. We were particularly interested, how far nominal wage formation in countries reflect the effects of a common currency and single monetary policy, and found that higher trade intensity does not exert such a synchronizing impact. With respect to unit labor costs, we conclude that productivity shocks are better distributed among the member countries and regions via higher trade, and are included into national wage formation.

Our second intention was to test the hypothesis that financial integration induces more specialization across countries and regions and, hence, allows a stronger impact of industry-specific effects on national formation. We found this strong positive impact of financial integration on specialization, but not the expected transfer on real wage or unit labor cost synchronization. We find more specialization to produce less synchronization for nominal wage dynamics only.

Finally, we found that financial integration explains the synchronization of real wage dynamics, but is coupled with a de-synchronization of nominal wage dynamics. In sum, our tests revealed, that national nominal wage formation is not endogenous in the EMU. National wage setters seem to include into the wage function the national inflation rate and not the area wide inflation rate, which should emerge through financial integration. The policy-relevant conclusion is that this behavior constitutes resistant asymmetries in labor market institutions and in an asymmetric nominal shock distribution across the Euro member countries. Notwithstanding, that different national inflation rates compensate for different nominal wage changes (= synchronized real wage dynamics), this result might explain the different development of unit labor costs (and trade imbalances) in the EMU: we have seen that financial integration, still contributing to synchronization of unit labor cost dynamics in the pre-Euro area, lost any significance since 1998. 


\section{References}

Andersen, T. M.; Seneca, M. (2008): Labour Market Asymmetries in a Monetary Union. CEPR Discussion Paper No. 6800.

Basevi, G. (1993): 'Discussion' (to Bayoumi and Eichengreen, 1993), in: F. Torres; F. Giavazzi (eds.), Growth and Adjustment in the European Monetary Union. Cambridge University Press: Oxford, pp. 230-35.

Bayoumi, T.; Eichengreen, B. (1993): Shocking Aspects of European Monetary Integration, in: F. Torres; F. Giavazzi (eds.), Growth and Adjustment in the European Monetary Union. Cambridge University Press: Oxford.

Calmfors, L. (2001): Wages and wage-bargaining institutions in the EMU - a survey of the issues. Seminar Paper No. 690. Institute for International Economic Studies. Stockholm University.

De Haan, J.; Inklaar, R.; Jong-A-Pin, R. (2008): Will Business Cycles in the Euro Area Converge? A Critical Survey of Empirical Research. Journal of Economic Surveys, Vol. 22, Issue 2, pp 234-273.

Deutsche Bundesbank (2007): Monatsbericht Juni 2007, S. 41-56.

Dullien, S.; Fritsche, U. (2007): Does the Dispersion of Unit Labor Cost Dynamics in the EMU Imply Long-run Divergence? Results from a Comparison with the United States of America and Germany. DEP Discussion Papers, 2/2007. Hamburg.

European Commission (2006): The EU Economy. Brussels.

Fischer, C. (2007): An Assessment of the Trends in International Price Competitiveness among EMU Countries. Discussion Paper des Forschungszentrum der Deutschen Bundesbank. S. 1, Nr. 8/2007

Frankel, J. A.; Andrew K. R. (1998): The Endogeneity of the Optimum Currency Area Criteria. The Economic Journal, 108 (July), pp. 1009-1025.

Holden, S. (2003): Monetary Regimes and the Co-ordination of Wage Setting. Department of Economics, University of Oslo (2003 Version on internet).

Imbs, J. (2004): Trade, Finance, Specialization, and Synchronization. Review of Economics and Statistics, 86 (3), pp. 723-734.

Ingram, J. (1973): The Case for European Monetary Integration. Princeton Essays in International Finance No 98 (April). Princeton: New Jersay.

Kalemli-Oczan, S. (2003): Risk Sharing and Industrial Specialization: Regional and International Evidence. American Economic Review, vol. 93 (3), pp. 903-19.

Krugman, P. (1993): Lessons of Massachusetts for EMU, in: F. Giavazzi; F. Torres, (eds), The Transition to Economic and Monetary Union in Europe. Cambridge University Press: New York, pp. 241-61. 
Lucas, R. E. (1976): Econometric Policy Evaluation. Carnegie Rochester Conference Series on Public Policy, Vol. 1, 1976, $19-46$.

Mann-Quirici, F. (2005): The Endogeneity of Optimum Currency Area Criteria - Lessons from History for European Monetary Union. Journal of Economic Studies, Vol. 32 (5), pp. 387-405.

Meade, J. (1957): The Balance of Payments Problems of a Free Trade Area. Economic Journal, 67, pp. 379-96.

Mongelli, F. P.; Juan L. V. (2006): What Effects is EMU having on the Euro Area and its Member Countries? An Overview. Working Paper Series, No. 599.

Mundell, R. (1961): A Theory of Optimum Currency Areas. American Economic Review 51 (4), pp. 657-65.

Otto, G.; Voss, G.; Willard, L. (2001): Undersanding OECD Output Correlations. Research Discussion Paper 2001-05. Reserve Bank of Australia.

Schiavo, S. (2005): Financial Integration, GDP Correlation and the Endogeneity of Optimum Currency Areas. Working Papers No. 25. Universitá di Verona.

Silva, S. J. (2005): Is the Euro Working? The Euro and European Labour Markets. Journal of Public Policy, 24 (2), pp. 147-168.

Soskice, D.; Iwersen, T. (2000): The non-neutrality of monetary policy with large price or wage setters. Quarterly Journal of Economics CXV, pp. 265-84.

Traxler, F. (2002): Wage Policy, Bargaining Institutions and Monetary Policy: Empirical Findings and Policy Implications for European Monetary Union, in: P. Pochet (ed.), Wage Policy in the Eurozone. P.I.E.-Peter Lang: Bruxelles 2002, pp. 111-130. 


\section{Appendices}

\section{Appendix A: Distribution of correlation coefficients and OLS estimates}

Table A1:

The distribution of signs of bilateral correlation coefficients (55 observations) - growth rates

\begin{tabular}{|c|c|c|c|c|c|c|c|c|c|}
\hline \multirow[b]{2}{*}{ Signs } & \multicolumn{3}{|c|}{$\Delta \log (\mathrm{ULC})$} & \multicolumn{3}{|c|}{$\Delta \log (\mathrm{NCE})$} & \multicolumn{3}{|c|}{$\Delta \log (\mathrm{RCE})$} \\
\hline & $\begin{array}{l}1981- \\
1989\end{array}$ & $\begin{array}{l}1990- \\
1997\end{array}$ & $\begin{array}{l}1998- \\
2007\end{array}$ & $\begin{array}{l}1981- \\
1989\end{array}$ & $\begin{array}{l}1990- \\
1997\end{array}$ & $\begin{array}{l}1998- \\
2007\end{array}$ & $\begin{array}{l}1981- \\
1989\end{array}$ & $\begin{array}{l}1990- \\
1997\end{array}$ & $\begin{array}{l}1998- \\
2007\end{array}$ \\
\hline \multicolumn{10}{|l|}{ All observations } \\
\hline \multirow{2}{*}{$\begin{array}{l}\text { Positive } \\
\text {...of which significant }{ }^{\mathrm{a}}\end{array}$} & 41 & 25 & 44 & 37 & 30 & 36 & 41 & 25 & 41 \\
\hline & 18 & 14 & 17 & 12 & 13 & 10 & 19 & 14 & 8 \\
\hline \multirow{2}{*}{$\begin{array}{l}\text { Negative } \\
\text {...of which signifikant }{ }^{\mathrm{a}}\end{array}$} & 14 & 30 & 11 & 18 & 25 & 19 & 14 & 30 & 14 \\
\hline & 2 & 9 & 0 & 0 & 8 & 2 & 2 & 9 & 1 \\
\hline \multirow{3}{*}{$\begin{array}{l}\text { Change as against previous } \\
\text { period } \\
\text {...from negative to positive } \\
\text {...from positive to negative }\end{array}$} & & & & & & & & & \\
\hline & - & 26 & 10 & -- & 7 & 6 & -- & 16 & 16 \\
\hline & - & 13 & 23 & -- & 7 & 6 & -- & 16 & 16 \\
\hline \multicolumn{10}{|c|}{ only observations with $\rho_{i, j, \tau}>|0,5|$} \\
\hline \multirow{2}{*}{$\begin{array}{l}\text { Positive } \\
\text {...of which significant }{ }^{\mathrm{a}}\end{array}$} & 21 & 14 & 9 & 17 & 14 & 11 & 18 & 14 & 10 \\
\hline & 17 & 12 & 7 & 13 & 14 & 10 & 18 & 14 & 8 \\
\hline \multirow{2}{*}{$\begin{array}{l}\text { Negative } \\
\text {...of which significant }{ }^{\mathrm{a}}\end{array}$} & 0 & 5 & 5 & 2 & 9 & 3 & 2 & 9 & 1 \\
\hline & 0 & 1 & 1 & 0 & 9 & 2 & 2 & 9 & 1 \\
\hline
\end{tabular}

${ }^{\text {a }}$ Significant at a level of at least $10 \%$.

Source: Authors' calculation, based on Ameco data. 
Table A2:

Descriptive statistics of the dependent variables (logistically transformed bilateral correlation coefficients, first differenced data) ${ }^{\mathrm{a}}$

\begin{tabular}{|l|c|c|c|c|c|c|}
\hline & Mean & Median & Maximum & Minimum & $\begin{array}{c}\text { Standard } \\
\text { deviation }\end{array}$ & JB-Statistic \\
\hline $\log (\mathrm{NCE})$ & 0.569 & 0.451 & 3.596 & -1.323 & 1.138 & 2.664 \\
$1980-1989$ & 0.618 & 0.711 & 3.160 & -1.256 & 1.031 & 0.985 \\
\hline $\log (\mathrm{NCE})$ & 0.255 & 0.229 & 4.975 & -2.864 & 1.610 & 1.554 \\
$1990-1997$ & 0.182 & 0.229 & 3.242 & -2.835 & 1.385 & 0.199 \\
\hline $\log (\mathrm{NCE})$ & 0.403 & 0.338 & 2.532 & -1.616 & 1.022 & 1.674 \\
$1998-2007$ & 0.394 & 0.339 & 2.532 & -1.616 & 1.009 & 1.349 \\
\hline $\log (\mathrm{RCE})$ & 0.700 & 0.708 & 3.165 & -1.655 & 1.113 & 0.676 \\
$1980-1989$ & 0.647 & 0.608 & 3.046 & -1.655 & 1.038 & 0.577 \\
\hline $\log (\mathrm{RCE})$ & 0.313 & -0.119 & 4.487 & -2.496 & 1.761 & $5.508^{*}$ \\
$1990-1997$ & 0.230 & -0.119 & 4.487 & -2.496 & 1.625 & $7.184 * *$ \\
\hline $\log (\mathrm{RCE})$ & 0.484 & 0.491 & 3.219 & -1.355 & 0.781 & $6.752^{* *}$ \\
$1998-2007$ & 0.441 & 0.491 & 1.643 & -1.355 & 0.700 & 1.229 \\
\hline $\log (\mathrm{ULC})$ & 0.662 & 0.561 & 3.396 & -1.045 & 1.005 & 1.494 \\
$1980-1989$ & 0.721 & 0.729 & 2.706 & -1.045 & 0.936 & 1.475 \\
\hline $\log (\mathrm{ULC})$ & 0.456 & 0.049 & 5.227 & -1.559 & 1.557 & $12.919 * * *$ \\
$1990-1997$ & 0.306 & 0.024 & 3.836 & -1.559 & 1.310 & $7.024 * *$ \\
\hline $\log (\mathrm{ULC})$ & 0.808 & 0.754 & 2.471 & -0.668 & 0.758 & 1.126 \\
$1998-2007$ & 0.827 & 0.723 & 2.471 & -0.618 & 0.749 & 0.896 \\
\hline
\end{tabular}

${ }^{a}$ Bivariate correlations of transformed correlation coefficients based on annual growth rates. **, $(* *),(*)$ indicates significance at the $1 \%,(5 \%),(10 \%)$ level. Recursive figures are related to the dataset with Netherlands excluded.

Source: Own calculation. 
Figure A2:

Plot of bivariate correlation coefficients using three wage measures (first differenced data)

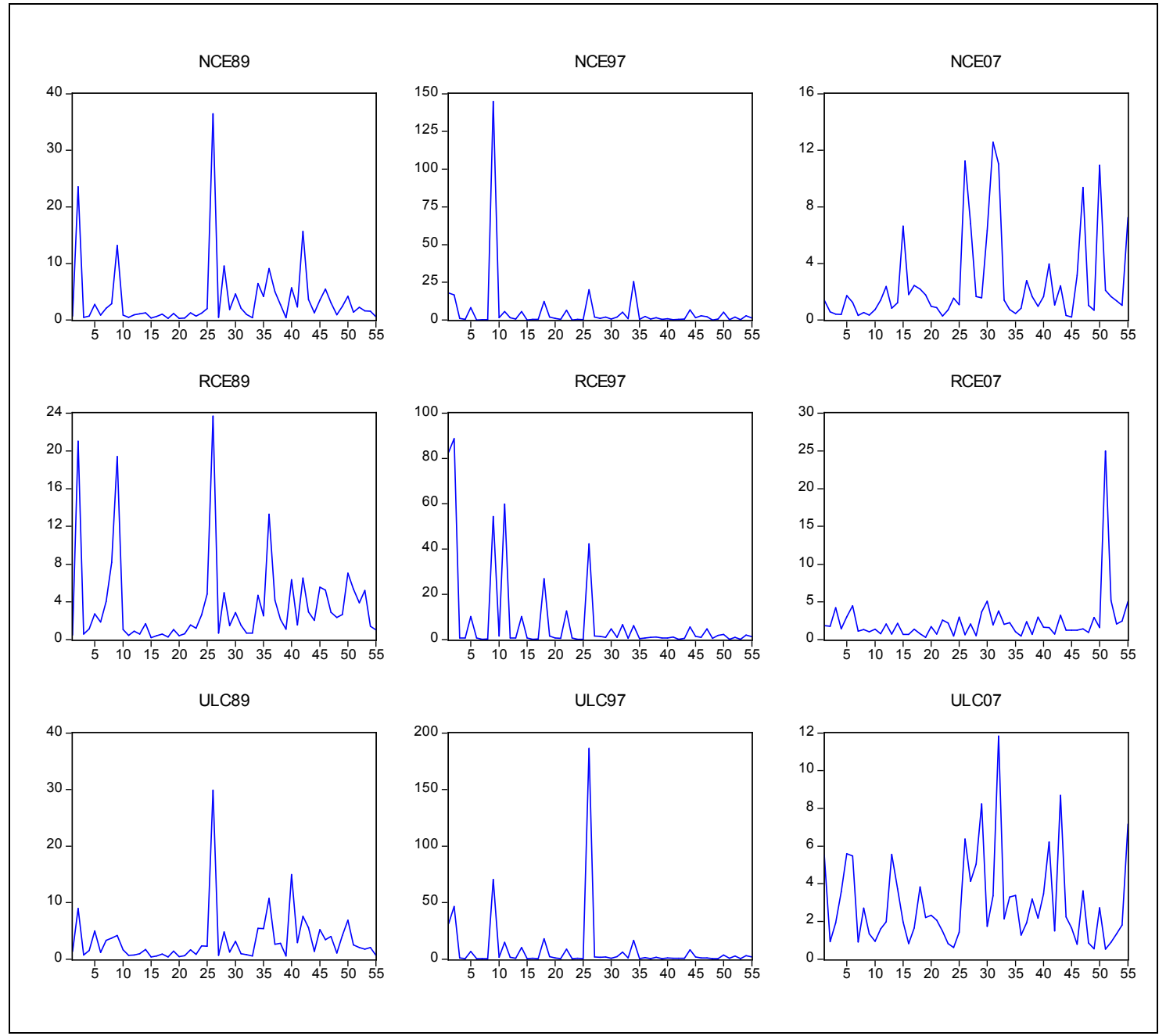

Source: Own calculation. 


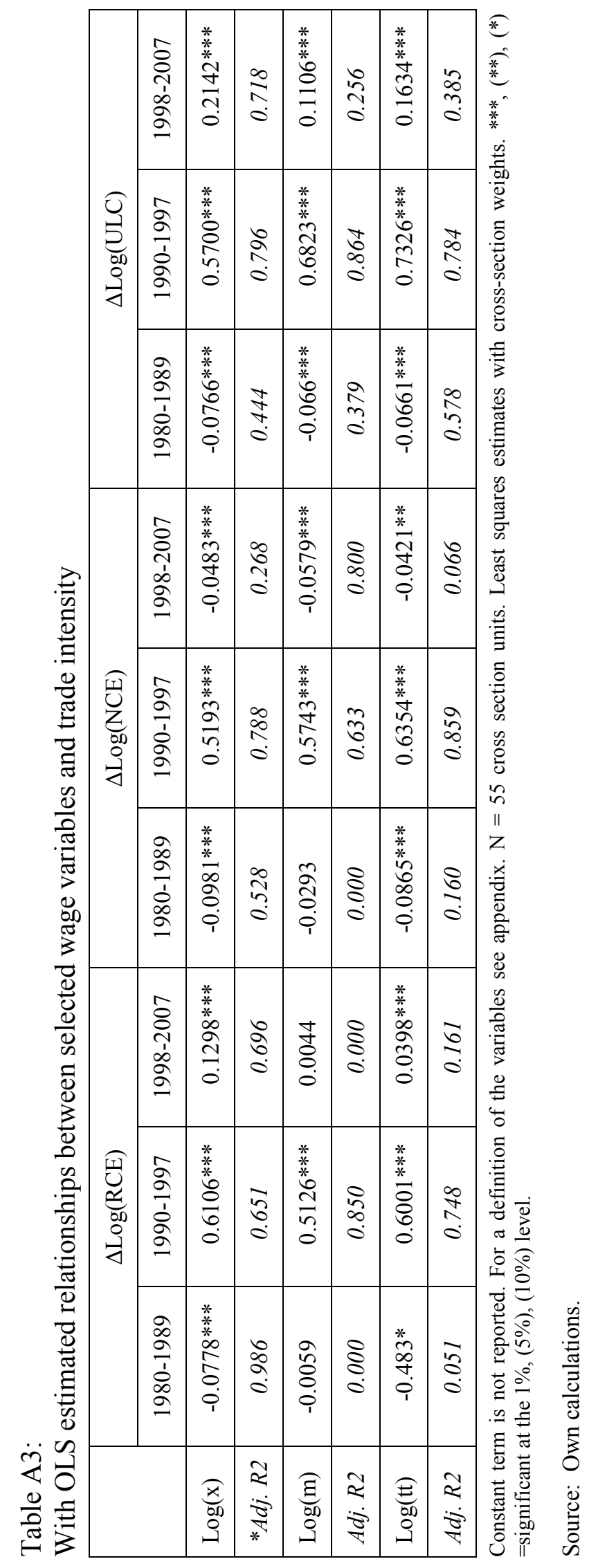




\section{Appendix B: Regression results in first differences $(N=55)$}

Table B4:

Instrumental variable estimates of relationships between selected wage variables and trade intensity measures

\begin{tabular}{|l|c|c|c|c|c|c|}
\hline \multirow{2}{*}{} & \multicolumn{2}{|c|}{$\Delta \log (\mathrm{RCE})$} & \multicolumn{2}{c|}{$\Delta \log (\mathrm{NCE})$} & \multicolumn{2}{c|}{$\Delta \log (\mathrm{ULC})$} \\
\cline { 2 - 7 } & $1990-1997$ & $1998-2007$ & $1990-1997$ & $1998-2007$ & $1990-1997$ & $1998-2007$ \\
\hline $\log (\mathrm{x})$ & $0.486^{* * *}$ & $0.140^{* * *}$ & $0.374 * * *$ & $-0.048 * * *$ & $0.551^{* * *}$ & $0.220^{* * *}$ \\
\hline Adj. $R 2$ & 0.548 & 0.825 & 0.864 & 0.478 & 0.855 & 0.724 \\
\hline $\log (\mathrm{m})$ & $0.546^{* * *}$ & $0.020^{*}$ & $0.539 * * *$ & $-0.080^{* * *}$ & $0.539 * * *$ & $-0.080^{* * *}$ \\
\hline Adj. $R 2$ & 0.822 & 0.042 & 0.840 & 0.905 & 0.840 & 0.905 \\
\hline $\log (\mathrm{tt})$ & $0.600^{* * *}$ & $0.058^{* * *}$ & $0.562 * * *$ & $-0.057 * * *$ & $0.690^{* * *}$ & $0.197 * * *$ \\
\hline Adj. $R 2$ & 0.753 & 0.895 & 0.645 & 0.442 & 0.747 & 0.493 \\
\hline
\end{tabular}

Constant term is not reported. For a definition of the variables see appendix. $\mathrm{N}=55$ cross section units. $*^{* *},(* *),(*)$ $=$ significant at the $1 \%,(5 \%),(10 \%)$ level. Instruments: the one period lagged explanatory variable, the distance measure and the dummy variable indicating a joint border or not. Due to the lagged instruments, only two periods remain for estimation.

Source: Own calculations.

Table B6:

Cross section estimates of real wages, IV estimates

\begin{tabular}{|l|r|r|r|r|r|c|}
\hline & \multicolumn{7}{|c|}{ Dependent variable: $\Delta \log (\mathrm{RCE})$} \\
\cline { 2 - 7 } & $1990-1997$ & $1998-2007$ & $1990-1997$ & $1998-2007$ & $1990-1997$ & $1998-2007$ \\
\hline Constant & $-1.093^{* * *}$ & $-10.241^{* * *}$ & 0.205 & -3.791 & -0.921 & $-9.569^{* * *}$ \\
\hline $\log (\mathrm{x})$ & $0.536^{* * *}$ & $0.505^{* * *}$ & & & & \\
\hline $\log (\mathrm{m})$ & & & $0.835^{* * *}$ & $0.282^{* *}$ & & \\
\hline $\log (\mathrm{tt})$ & & & & & $0.663^{* * *}$ & $0.525^{* * *}$ \\
\hline $\log (\mathrm{sp})$ & $1.302^{* * *}$ & $3.628^{* * *}$ & $1.207 * *$ & 1.602 & $1.357^{* * *}$ & $3.505^{* * *}$ \\
\hline $\log (\mathrm{fi})$ & $-0.748^{* * *}$ & $-0.086^{* * *}$ & -0.292 & 0.065 & $-0.575^{* * *}$ & 0.018 \\
\hline R2 adj. & 0.904 & 0.990 & 0.877 & 0.508 & 0.825 & 0.746 \\
\hline Nobs & 55 & 55 & 55 & 55 & 55 & 55 \\
\hline
\end{tabular}

For a definition of the variables see appendix. $\mathrm{N}=55$ cross section units. Least squares estimates with cross-section weights. ${ }^{* * *},(* *),(*)=$ significant at the $1 \%,(5 \%),(10 \%)$ level. Instruments: $\log ($ distance $)$, common border, 1 period lagged $\log (\mathrm{sp}), 1$-period lagged $\log (\mathrm{fi})$, constant.

Source: Own calculations. 
Table B7:

Cross section estimates of nominal wage per employee (log(nce)), IV estimates

\begin{tabular}{|l|c|c|c|c|c|c|}
\hline \multirow{2}{*}{} & \multicolumn{7}{|c|}{ Dependent variable: $\Delta \log (\mathrm{NCE})$} \\
\cline { 2 - 7 } & $1990-1997$ & $1998-2007$ & $1990-1997$ & $1998-2007$ & $1990-1997$ & $1998-2007$ \\
\hline Constant & 1.577 & $10.369^{* *}$ & 2.314 & $6.673^{* * *}$ & 1.940 & 9.481 \\
\hline $\log (\mathrm{ex})$ & $0.228^{* * *}$ & $-0.418^{* * *}$ & & & & \\
\hline $\log (\mathrm{im})$ & & & 0.173 & $-0.252^{* * *}$ & & \\
\hline $\log (\mathrm{tt})$ & & & & & $0.198^{*}$ & $-0.498^{* * *}$ \\
\hline $\log (\mathrm{sp})$ & 0.224 & $-3.146^{* *}$ & -0.041 & $-1.974 * * *$ & 0.088 & -3.069 \\
\hline $\log (\mathrm{fi})$ & $-0.847^{* * *}$ & $0.460^{* *}$ & $-0.854 * * *$ & $0.333^{* * *}$ & $-0.863^{* * *}$ & 0.357 \\
\hline R2 adj. & 0.911 & 0.919 & 0.887 & 0.996 & 0.911 & 0.379 \\
\hline Nobs & 55 & 55 & 55 & 55 & 55 & 55 \\
\hline
\end{tabular}

For a definition of the variables see appendix. $\mathrm{N}=55$ cross section units. Least squares estimates with cross-section weights. ${ }^{* * *},(* *),(*)=$ significant at the $1 \%,(5 \%),(10 \%)$ level. Instruments: $\log ($ distance $)$, joint border, 1 -period lagged $\log (\mathrm{sp}), 1$-period lagged $\log (\mathrm{fi})$, constant.

Source: Own calculations.

Table B8:

Cross section estimates of unit labor costs $(\log (\mathrm{ulc}))$, IV estimates

\begin{tabular}{|l|c|c|c|c|c|c|}
\hline & \multicolumn{7}{|c|}{ Dependent variable: $\Delta \log (\mathrm{ULC})$} \\
\cline { 2 - 7 } & $1990-1997$ & $1998-2007$ & $1990-1997$ & $1998-2007$ & $1990-1997^{\mathrm{a}}$ & $1998-2007^{\mathrm{a}}$ \\
\hline Constant & 0.266 & $4.032^{* * *}$ & 0.010 & $9.056^{* * *}$ & $-0.575^{* * *}$ & $1.320^{* *}$ \\
\hline $\log (\mathrm{ex})$ & 0.304 & $0.091^{* * *}$ & & & & \\
\hline $\log (\mathrm{im})$ & & & $0.358^{* * *}$ & $-0.256^{* * *}$ & & \\
\hline $\log (\mathrm{tt})$ & & & & & $0.360^{* * *}$ & $0.211^{* * *}$ \\
\hline $\log (\mathrm{sp})$ & $0.824 * * *$ & $-0.793^{* * *}$ & $0.929 * * *$ & $-2.709 * * *$ & $1.084 * * *$ & 0.116 \\
\hline $\log (\mathrm{fi})$ & $-1.085^{* * *}$ & 0.002 & $-0.986^{* * *}$ & -0.079 & $1.032^{* * *}$ & -0.031 \\
\hline R2 adj. & 0.993 & 0.865 & 0.998 & 0.919 & 0.981 & 0.563 \\
\hline Nobs & 55 & 55 & 55 & 55 & 55 & 55 \\
\hline
\end{tabular}

For a definition of the variables see appendix. $\mathrm{N}=55$ cross section units. Least squares estimates with cross-section weights. ${ }^{* *},(* *),(*)=$ significant at the $1 \%,(5 \%),(10 \%)$ level. Instruments: $\log ($ distance $)$, joint border, 1 -period lagged $\log (\mathrm{sp}), 1$-period lagged $\log (\mathrm{fi})$, constant. a) as additional instrument $\log (\operatorname{tt}(-1))$ has been used.

Source: Own calculations. 


\section{Appendix C: Regression results in first differences with the Netherlands excluded}

Table C4:

Instrumental variable estimates of relationships between selected wage variables and trade intensity measures, $\mathrm{N}=45$ (The Netherlands excluded)

\begin{tabular}{|l|c|c|c|c|c|c|}
\hline \multirow{2}{*}{} & \multicolumn{2}{|c|}{$\Delta \log (\mathrm{RCE})$} & \multicolumn{2}{c|}{$\Delta \log (\mathrm{NCE})$} & \multicolumn{2}{c|}{$\Delta \log (\mathrm{ULC})$} \\
\cline { 2 - 7 } & $1990-1997$ & $1998-2007$ & $1990-1997$ & $1998-2007$ & $1990-1997$ & $1998-2007$ \\
\hline $\log (\mathrm{x})$ & $0.320^{* * *}$ & $0.161 * * *$ & $0.260^{* * *}$ & $-0.098^{* * *}$ & $0.368^{* * *}$ & $0.185^{* * *}$ \\
\hline Adj. $R 2$ & 0.513 & 0.949 & 0.932 & 0.969 & 0.513 & 0.669 \\
\hline $\log (\mathrm{m})$ & $0.487 * * *$ & $0.087 * * *$ & $0.363 * * *$ & $-0.103 * * *$ & $0.535 * * *$ & $0.189 * * *$ \\
\hline Adj. $R 2$ & 0.872 & 0.737 & 0.656 & 0.991 & 0.748 & 0.664 \\
\hline $\log (\mathrm{tt})$ & $0.514 * * *$ & $0.144 * * *$ & $0.341^{* * *}$ & $-0.106^{* * *}$ & $0.431 * * *$ & $0.189 * * *$ \\
\hline Adj. $R 2$ & 0.895 & 0.765 & 0.548 & 0.997 & 0.442 & 0.718 \\
\hline
\end{tabular}

Constant term is not reported. For a definition of the variables see appendix. $\mathrm{N}=55$ cross section units. ${ }^{* * *},\left({ }^{* *}\right),\left({ }^{*}\right)$ $=$ significant at the $1 \%,(5 \%),(10 \%)$ level. Instruments: the one period lagged explanatory variable, the distance measure and the dummy variable indicating a joint border or not. Due to the lagged instruments, only two periods remain for estimation.

Source: Own calculations.

Table C5:

Estimates of the impact of financial integration on sector specialization $(\mathrm{N}=45$, without The Netherlands)

\begin{tabular}{|l|l|l|r|r|l|}
\hline & Constant & $\log (\mathrm{FI})$ & R2(adj.) & \multicolumn{1}{|c|}{ Period } & \multicolumn{1}{|c|}{ Instruments } \\
\hline 1 & $3.649 * * *$ & $0.132 * * *$ & 0.504 & $1980-1989$ & OLS \\
\hline 2 & $3.498 * * *$ & $0.172 * * *$ & & $1990-1997$ & OLS \\
\hline 3 & $3.594 * * *$ & $0.118 * * *$ & 0.917 & $1990-1997$ & IV: const, $\log (\mathrm{FI}(-1))$ \\
\hline 4 & $3.619 * * *$ & $0.054 * * *$ & 0.414 & $1998-2007$ & OLS \\
\hline 5 & $3.753 * * *$ & $0.148 * * *$ & 0.688 & $1998-2007$ & IV: const, $\log (\mathrm{FI}(-1))$ \\
\hline
\end{tabular}

$* * *=$ significant at the $1 \%$ level; OLS = ordinary least squares regression; IV = instrument variable estimation. Estimation with cross section weights.

Source: Own calculations. 
Table C6:

Cross section estimates of real wages, IV estimates, The Netherlands excluded

\begin{tabular}{|l|c|c|c|c|c|c|}
\hline \multirow{2}{*}{} & \multicolumn{7}{|c|}{ Dependent variable: $\Delta \log (\mathrm{RCE})$} \\
\cline { 2 - 7 } & $1990-1997$ & $1998-2007$ & $1990-1997$ & $1998-2007$ & $1990-1997$ & $1998-2007$ \\
\hline Constant & 0.043 & $-9.134^{* * *}$ & -0.042 & -1.600 & $1.210^{* *}$ & $-7.025^{* * *}$ \\
\hline $\log (\mathrm{x})$ & $0.624^{* * *}$ & $0.466^{* * *}$ & & & & \\
\hline $\log (\mathrm{m})$ & & & $0.703^{* * *}$ & $0.231^{* * *}$ & & \\
\hline $\log (\mathrm{tt})$ & & & & & $0.780^{* * *}$ & $0.482^{* * *}$ \\
\hline $\log (\mathrm{sp})$ & $1.025^{* * *}$ & $3.245^{* * *}$ & $0.997^{* * *}$ & $0.958^{* *}$ & $0.830^{* * *}$ & $2.693^{* * *}$ \\
\hline $\log (\mathrm{fi})$ & $-0.468^{* * *}$ & $-0.126^{* *}$ & -0.056 & $0.104^{* *}$ & $-0.233^{* * *}$ & -0.089 \\
\hline R2 adj. & 0.826 & 0.986 & 0.913 & 0.695 & 0.853 & 0.983 \\
\hline Nobs & 45 & 45 & 45 & 45 & 45 & 45 \\
\hline
\end{tabular}

For a definition of the variables see appendix. $\mathrm{N}=55$ cross section units. Least squares estimates with cross-section weights. ${ }^{* *},(* *),(*)=$ significant at the $1 \%,(5 \%),(10 \%)$ level. Instruments: $\log ($ distance $)$, common border, 1 period lagged $\log (\mathrm{sp}), 1$-period lagged $\log (\mathrm{fi})$, constant.

Source: Own calculations.

Table C7:

Cross section estimates of nominal wage per employee $(\log (\mathrm{nce}))$, IV estimates. The Netherlands excluded

\begin{tabular}{|l|c|c|c|c|c|c|}
\hline \multirow{2}{*}{} & \multicolumn{7}{|c|}{ Dependent variable: $\Delta \log (\mathrm{NCE})$} \\
\cline { 2 - 7 } & $1990-1997$ & $1998-2007$ & $1990-1997$ & $1998-2007$ & $1990-1997$ & $1998-2007$ \\
\hline Constant & $2.327^{* * *}$ & $6.411^{* *}$ & $2.973^{* *}$ & $8.214^{* * *}$ & $2.447^{* * *}$ & $6.862^{* *}$ \\
\hline $\log (\mathrm{ex})$ & $0.266^{* * *}$ & $-0.448^{* * *}$ & & & & \\
\hline $\log (\mathrm{im})$ & & & $0.455^{* * *}$ & $-0.739^{* * *}$ & & \\
\hline $\log (\mathrm{tt})$ & & & & & $0.349^{* * *}$ & $-0.593^{* * *}$ \\
\hline $\log (\mathrm{sp})$ & -0.056 & $-2.168^{* * *}$ & -0.071 & $-3.188^{* * *}$ & -0.028 & $-2.555^{* * *}$ \\
\hline $\log (\mathrm{fi})$ & $-0.426^{* * *}$ & 0.282 & -0.186 & 0.052 & $-0.327^{* * *}$ & 0.166 \\
\hline R2 adj. & 0.783 & 0.805 & 0.571 & 0.461 & 0.653 & 0.668 \\
\hline Nobs & 45 & 45 & 45 & 45 & 45 & 45 \\
\hline
\end{tabular}

For a definition of the variables see appendix. $\mathrm{N}=55$ cross section units. Least squares estimates with cross-section weights. $* * *,(* *),(*)=$ significant at the $1 \%,(5 \%),(10 \%)$ level. Instruments: $\log ($ distance $)$, joint border, 1 -period lagged $\log (\mathrm{sp}), 1$-period lagged $\log (\mathrm{fi})$, constant.

Source: Own calculations. 
Table C8:

Cross section estimates of unit labor costs $(\log (\mathrm{ulc}))$, IV estimates; The Netherlands excluded

\begin{tabular}{|l|r|r|r|r|r|r|}
\hline & \multicolumn{7}{|c|}{ Dependent variable: $\Delta \log (\mathrm{ULC})$} \\
\cline { 2 - 7 } & $1990-1997$ & $1998-2007$ & $1990-1997$ & $1998-2007$ & $1990-1997^{\mathrm{a}}$ & $1998-2007^{\mathrm{a}}$ \\
\hline Constant & $1.538^{* *}$ & $-4.408^{* * *}$ & -0.305 & $3.211^{*}$ & $1.867^{* *}$ & $-5.173^{* * *}$ \\
\hline $\log (\mathrm{ex})$ & $0.461^{* * *}$ & $0.219^{* * *}$ & & & & \\
\hline $\log (\mathrm{im})$ & & & $0.282^{* *}$ & 0.137 & & \\
\hline $\log (\mathrm{tt})$ & & & & & $0.392^{* *}$ & $0.238^{* * *}$ \\
\hline $\log (\mathrm{sp})$ & $0.482^{* * *}$ & $1.657^{* * *}$ & $0.887^{* * *}$ & -0.494 & $0.342^{* *}$ & $1.904 * * *$ \\
\hline $\log (\mathrm{fi})$ & $-0.623^{* * *}$ & $-0.254^{* * *}$ & $-0.915^{* * *}$ & -0.000 & $-0.672^{* * *}$ & $-0.272^{* * *}$ \\
\hline R2 adj. & 0.969 & 0.997 & 0.993 & 0.224 & 0.924 & 0.686 \\
\hline Nobs & 45 & 45 & 45 & 45 & 45 & 45 \\
\hline
\end{tabular}

For a definition of the variables see appendix. $\mathrm{N}=55$ cross section units. Least squares estimates with cross-section weights. $* * *,(* *),(*)=$ significant at the $1 \%,(5 \%),(10 \%)$ level. Instruments: $\log ($ distance $)$, joint border, 1 -period lagged $\log (\mathrm{sp})$, 1-period lagged $\log (\mathrm{fi})$, constant. a) as additional instrument $\log (\mathrm{tt}(-1))$ has been used.

Source: Own calculations. 


\section{Appendix D: Regression results in first differences - dummy Netherlands included}

Table D4:

Instrumental variable estimates of relationships between selected wage variables and trade intensity measures

\begin{tabular}{|l|c|c|c|c|c|c|}
\hline \multirow{2}{*}{} & \multicolumn{2}{|c|}{$\Delta \log (\mathrm{RCE})$} & \multicolumn{2}{c|}{$\Delta \log (\mathrm{NCE})$} & \multicolumn{2}{c|}{$\Delta \log (\mathrm{ULC})$} \\
\cline { 2 - 7 } & $1990-1997$ & $1998-2007$ & $1990-1997$ & $1998-2007$ & $1990-1997$ & $1998-2007$ \\
\hline $\log (\mathrm{x})$ & $0.898^{* * *}$ & $-0.043^{* *}$ & $0.778^{* * *}$ & $-0153^{* * *}$ & $0.962 * * *$ & $0.167 * * *$ \\
\hline $\begin{array}{l}\text { NL dum- } \\
\text { my }\end{array}$ & 0.171 & $0.243^{* * *}$ & 0.141 & -0.005 & $0.455^{* * *}$ & $-0.135^{* * *}$ \\
\hline Adj. $R 2$ & 0.954 & 0.844 & 0.948 & 0.664 & 0.994 & 0.874 \\
\hline $\log (\mathrm{m})$ & $0.992^{* * *}$ & $-0.064^{* * *}$ & $0.792^{* * *}$ & $-0.176^{* * *}$ & $0.981^{* * *}$ & $0.177 * * *$ \\
\hline $\begin{array}{l}\text { NL dum- } \\
\text { my }\end{array}$ & -0.206 & $0.343^{* * *}$ & -0.090 & $0.155^{* * *}$ & $0.172^{*}$ & $-0.270^{* * *}$ \\
\hline Adj. $R 2$ & 0.712 & 0.634 & 0.986 & 0.679 & 0.981 & 0.502 \\
\hline Log(tt) & $1.034 * *$ & $-0.043^{* * *}$ & $0.795^{* * *}$ & $-0.155^{* * *}$ & $0.996^{* * *}$ & $0.183^{* * *}$ \\
\hline $\begin{array}{l}\text { NL dum- } \\
\text { my }\end{array}$ & -0.182 & $0.271 * * *$ & -0.020 & 0.044 & $0.395^{* *}$ & $-0.212^{* * *}$ \\
\hline Adj. $R 2$ & 0.855 & 0.924 & 0.945 & 0.759 & 0.966 & 0.627 \\
\hline
\end{tabular}

Constant term is not reported. For a definition of the variables see appendix. $\mathrm{N}=55$ cross section units. ${ }^{* * *},\left({ }^{* *}\right),\left({ }^{*}\right)$ $=$ significant at the $1 \%,(5 \%),(10 \%)$ level. Instruments: the distance measure and the dummy variable indicating a joint border or not, the dummy for the Netherlands, constant term.

Source: Own calculations.

Table D5:

Estimates of the impact of financial integration on sector specialization

\begin{tabular}{|c|c|c|c|c|c|c|}
\hline & Constant & $\log (\mathrm{FI})$ & NL-dum & R2(adj.) & Period & Instruments \\
\hline 1 & $3.708 * * *$ & $0.098 * * *$ & $0.247 * * *$ & 0.878 & 1980-1989 & OLS \\
\hline 2 & $3.541 * * *$ & $0.147^{* * *}$ & 0.037 & 0.947 & 1990-1997 & OLS \\
\hline 3 & $3.592 * * *$ & $0.121 * * *$ & 0.030 & 0.791 & 1990-1997 & $\begin{array}{l}\text { IV: const, } \log (\mathrm{FI}(-1)) \text {, } \\
\text { NL-dum }\end{array}$ \\
\hline 4 & $3.567 * * *$ & $0.132 * * *$ & $0.039 * * *$ & 0.969 & 1990-1997 & $\begin{array}{l}\text { IV: const, } \log (\mathrm{FI}(-1)), \text { joint } \\
\text { border, } \log (\text { distance }), \\
\text { NL-dum }\end{array}$ \\
\hline 5 & $3.646^{* * *}$ & $0.075 * * *$ & $0.094 * * *$ & 0.976 & $1998-2007$ & OLS \\
\hline 6 & $3.761 * * *$ & $0.158 * * *$ & $0.136 * * *$ & 0.993 & $1998-2007$ & $\begin{array}{l}\text { IV: const, } \log (\mathrm{FI}(-1)) \text {, } \\
\text { NL-dum }\end{array}$ \\
\hline 7 & $3.765 * * *$ & $0.160 * * *$ & $0.135 * * *$ & 0.950 & $1998-2007$ & $\begin{array}{l}\text { IV: const, } \log (\mathrm{FI}(-1)) \text {, joint } \\
\text { border, } \log (\text { distance }) \text {, } \\
\text { NL-dum }\end{array}$ \\
\hline
\end{tabular}

$* * *=$ significant at the $1 \%$ level; OLS = ordinary least squares regression; IV = instrument variable estimation. Estimation with cross section weights.

Source: Own calculations. 
Table D6:

Cross section estimates of real wages, IV estimates

\begin{tabular}{|l|c|c|c|c|c|c|}
\hline \multirow{2}{*}{} & \multicolumn{7}{|c|}{ Dependent variable: $\Delta \log (\mathrm{RCE})$} \\
\cline { 2 - 7 } & $1990-1997$ & $1998-2007$ & $1990-1997$ & $1998-2007$ & $1990-1997$ & $1998-2007$ \\
\hline Constant & $-1.105^{* *}$ & $-11.719^{* * *}$ & -1.591 & $-15.088^{* * *}$ & -0.872 & $-15.324^{* * *}$ \\
\hline $\log (\mathrm{x})$ & $0.563^{* * *}$ & $0.484^{* * *}$ & & & & \\
\hline $\log (\mathrm{m})$ & & & $0.707^{* * *}$ & $0.763^{* * *}$ & & \\
\hline $\log (\mathrm{tt})$ & & & & & $0.689^{* * *}$ & $0.773^{* * *}$ \\
\hline $\log (\mathrm{fi})$ & $-0.759^{* * *}$ & $-0.161^{* * *}$ & $-0.567^{* *}$ & -0.029 & $-0.618^{* * *}$ & -0.166 \\
\hline $\log (\mathrm{sp})$ & $1.354^{* * *}$ & $4.011^{* * *}$ & $1.625^{* * *}$ & $5.438^{* * *}$ & $1.410^{* * *}$ & $5.403^{* * *}$ \\
\hline NL-dummy & -0.164 & $-0.285^{* *}$ & -0.167 & $-0.537^{* * *}$ & $-0.272^{* *}$ & $-0.476^{* * *}$ \\
\hline R2 adj. & 0.824 & 0.974 & 0.765 & 0.909 & 0.772 & 0.925 \\
\hline Nobs & 55 & 55 & 55 & 55 & 55 & 55 \\
\hline
\end{tabular}

For a definition of the variables see appendix. $\mathrm{N}=55$ cross section units. Least squares estimates with cross-section weights. ${ }^{* * *},(* *),(*)=$ significant at the $1 \%,(5 \%),(10 \%)$ level. Instruments: $\log ($ distance $)$, common border, 1 period lagged $\log (\mathrm{sp}), 1$-period lagged $\log (\mathrm{fi})$, constant.

Source: Own calculations.

Table D7:

Cross section estimates of nominal wage per employee (log(nce)), IV estimates

\begin{tabular}{|l|c|r|c|c|c|c|}
\hline & \multicolumn{7}{|c|}{ Dependent variable: $\Delta \log (\mathrm{NCE})$} \\
\cline { 2 - 7 } & $1990-1997$ & $1998-2007$ & $1990-1997$ & $1998-2007$ & $1990-1997$ & $1998-2007$ \\
\hline Constant & 1.459 & $15.582 * * *$ & 1.436 & $17.367 * * *$ & 1.525 & $15.982 * * *$ \\
\hline $\log (\mathrm{x})$ & $0.272 * * *$ & $-0.469 * * *$ & & & & \\
\hline $\log (\mathrm{m})$ & & & $0.254 * *$ & $-0.770 * * *$ & & \\
\hline $\log (\mathrm{tt})$ & & & & & $0.272 * * *$ & $-0.642 * * *$ \\
\hline $\log (\mathrm{fi})$ & $-0.828^{* * *}$ & $0.699^{* *}$ & $-0.777 * * *$ & $0.392^{* * *}$ & $-0.803 * * *$ & $0.580 * * *$ \\
\hline $\log (\mathrm{sp})$ & 0.333 & $-4.604 * * *$ & 0.320 & $-5.700^{* * *}$ & 0.312 & $-5.004 * * *$ \\
\hline NL-dummy & -0.094 & $0.733^{* * *}$ & -0.225 & $1.078 * * *$ & -0.146 & $0.934 * * *$ \\
\hline R2 adj. & 0.942 & 0.629 & 0.958 & 0.749 & 0.946 & 0.946 \\
\hline Nobs & 55 & 55 & 55 & 55 & 55 & 55 \\
\hline
\end{tabular}

For a definition of the variables see appendix. $\mathrm{N}=55$ cross section units. Least squares estimates with cross-section weights. $* * *,(* *),(*)=$ significant at the $1 \%,(5 \%),(10 \%)$ level. Instruments: $\log ($ distance $)$, joint border, 1 -period lagged $\log (\mathrm{sp}), 1$-period lagged $\log (\mathrm{fi})$, constant.

Source: Own calculations. 
Table D8:

Cross section estimates of unit labor costs $(\log ($ ulc $))$, IV estimates

\begin{tabular}{|l|c|c|c|c|c|c|}
\hline & \multicolumn{7}{|c|}{ Dependent variable: $\Delta \log (\mathrm{ULC})$} \\
\cline { 2 - 7 } & $1990-1997$ & $1998-2007$ & $1990-1997$ & $1998-2007$ & $1990-1997^{\mathrm{a}}$ & $1998-2007^{\mathrm{a}}$ \\
\hline Constant & 0.459 & 0.581 & -0.002 & $2.455^{* * *}$ & -1.139 & 3.079 \\
\hline $\log (\mathrm{ex})$ & $0.312^{* *}$ & $0.187^{* * *}$ & & & & \\
\hline $\log (\mathrm{im})$ & & & $0.383^{* * *}$ & $0.192^{* * *}$ & & \\
\hline $\log (\mathrm{tt})$ & & & & & 0.167 & $0.156^{* * *}$ \\
\hline $\log (\mathrm{fi})$ & $-1.081^{* * *}$ & $-0.102^{* *}$ & $-0.978^{* * *}$ & 0.002 & $-1.216^{* * *}$ & -0.037 \\
\hline $\log (\mathrm{sp})$ & $0.775^{* * *}$ & 0.276 & $0.959^{* * *}$ & -0.194 & $1.083^{* * *}$ & -0.453 \\
\hline NL-Dummy & 0.015 & $-0.227^{* *}$ & -0.124 & $-0.217^{* * *}$ & 0.001 & -0.109 \\
\hline R2 adj. & 0.989 & 0.517 & 0.985 & 0.841 & 0.986 & 0.857 \\
\hline Nobs & 55 & 55 & 55 & 55 & 55 & 55 \\
\hline
\end{tabular}

For a definition of the variables see appendix. $\mathrm{N}=55$ cross section units. Least squares estimates with cross-section weights. ${ }^{* *},(* *),(*)=$ significant at the $1 \%,(5 \%),(10 \%)$ level. Instruments: $\log ($ distance), joint border, 1 -period lagged $\log (\mathrm{sp}), 1$-period lagged $\log (\mathrm{fi})$, constant. a) as additional instrument $\log (\operatorname{tt}(-1))$ has been used.

Source: Own calculations. 


\section{Appendix E: Regression results with HP-filtered data, Netherlands dummy variable included $(\mathrm{N}=\mathbf{5 5})$}

Table E4:

Instrumental variable estimates of relationships between selected wage variables and trade intensity measures, $\mathrm{N}=55$

\begin{tabular}{|l|c|c|c|c|c|c|}
\hline \multirow{2}{*}{} & \multicolumn{2}{|c|}{ HP_Log(RCE) } & \multicolumn{2}{c|}{ HP_Log(NCE) } & \multicolumn{2}{c|}{ HP_Log(ULC) } \\
\cline { 2 - 7 } & $1990-1997$ & $1998-2007$ & $1990-1997$ & $1998-2007$ & $1990-1997$ & $1998-2007$ \\
\hline Log(x) & $0.495^{* * *}$ & $0.350^{* * *}$ & $0.606^{* * *}$ & 0.032 & $0.560^{* * *}$ & $0.425^{* * *}$ \\
\hline NL-dum & $0.624 * * *$ & 0.241 & $0.537 * * *$ & $0.622 * * *$ & $0.811^{* * *}$ & $0.548^{* * *}$ \\
\hline Adj. R2 & 0.792 & 0.681 & 0.948 & 0.400 & 0.624 & 0.874 \\
\hline Log(m) & $0.853^{* * *}$ & $0.086^{* * *}$ & $0.738^{* * *}$ & $-0.177 * * *$ & $0.902^{* * *}$ & $0.323^{* * *}$ \\
\hline NL-dum & 0.454 & 0.178 & 0.418 & $0.797 * * *$ & $0.581 *$ & $0.549 * * *$ \\
\hline Adj. R2 & 0.855 & 0.412 & 0.901 & 0.732 & 0.747 & 0.980 \\
\hline Log(tt) & $0.708^{* * *}$ & $0.207 * * *$ & $0.759 * * *$ & $-0.041 *$ & $0.823 * * *$ & $0.424 * * *$ \\
\hline NL-dum & $0.715^{* *}$ & 0.191 & 0.549 & $0.659 * * *$ & $0.866^{* *}$ & $0.463 * * *$ \\
\hline Adj. R2 & 0.932 & 0.352 & 0.585 & 0.418 & 0.552 & 0.974 \\
\hline
\end{tabular}

Constant term is not reported. For a definition of the variables see appendix. $\mathrm{N}=55$ cross section units. ${ }^{* * *},\left({ }^{* *}\right),\left({ }^{*}\right)$ $=$ significant at the $1 \%,(5 \%),(10 \%)$ level. Instruments: the distance measure and the dummy variable indicating a joint border or not, the dummy for the Netherlands, constant term., one period lagged explanatory variable.

Source: Own calculations.

Table E5:

Estimates of the impact of financial integration on sector specialization $(\mathrm{N}=55$, dummy for The Netherlands)

\begin{tabular}{|l|l|l|l|l|l|l|}
\hline & Constant & $\log (\mathrm{fi})$ & Dum_nl & R2(adj.) & Period & \multicolumn{1}{|c|}{ Instruments } \\
\hline 1 & $3.708 * * *$ & $0.098 * * *$ & $0.247 * * *$ & 0.878 & $1980-1989$ & OLS \\
\hline 2 & $3.541 * * *$ & $0.147 * * *$ & 0.037 & 0.947 & $1990-1997$ & OLS \\
\hline 3 & $3.592 * * *$ & $0.121 * * *$ & 0.030 & 0.791 & $1990-1997$ & IV: const, $\log (\mathrm{FI}(-1))$ \\
\hline 4 & $3.646 * * *$ & $0.075 * * *$ & $0.094 * * *$ & 0.976 & $1998-2007$ & OLS \\
\hline 5 & $3.761 * * *$ & $0.158 * * *$ & $0.136 * * *$ & 0.993 & $1998-2007$ & IV: $\operatorname{const}, \log (\mathrm{FI}(-1))$ \\
\hline
\end{tabular}

$* * *=$ significant at the $1 \%$ level; OLS = ordinary least squares regression; IV = instrument variable estimation. Estimation with cross section weights.

Source: Own calculations. 
Table E6:

Cross section estimates of real wages, IV estimates, dummy variable for The Netherlands

\begin{tabular}{|l|r|r|r|r|r|r|}
\hline & \multicolumn{7}{|c|}{ Dependent variable: HP_Log(RCE) } \\
\cline { 2 - 7 } & $1990-1997$ & $1998-2007$ & $1990-1997$ & $1998-2007$ & $1990-1997$ & $1998-2007$ \\
\hline Constant & -1.977 & $-8.523 * * *$ & $-4.648^{* * *}$ & -9.685 & $-2.985^{*}$ & -29.496 \\
\hline $\log (\mathrm{x})$ & $0.659 * * *$ & $0.334 * * *$ & & & & \\
\hline $\log (\mathrm{m})$ & & & $0.601 * * *$ & $0.394 * * *$ & & \\
\hline $\log (\mathrm{tt})$ & & & & & $0.681 * * *$ & 0.419 \\
\hline $\log (\mathrm{sp})$ & $\left.1.805^{*}\right)$ & $2.708^{* * * *}$ & $2.484^{* * *}$ & 3.206 & $2.109 * * *$ & 8.419 \\
\hline $\log (\mathrm{fi})$ & $-1.010^{* * *}$ & $-0.292^{* *}$ & $-1.146^{* * *}$ & -0.151 & $-1.086^{* * *}$ & -1.192 \\
\hline Neth-dum & -0.129 & -0.271 & -0.315 & -0.323 & -0.286 & -0.882 \\
\hline R2 adj. & 0.897 & 0.738 & 0.905 & 0.764 & 0.877 & 0.000 \\
\hline Nobs & 55 & 55 & 55 & 55 & 55 & 55 \\
\hline
\end{tabular}

For a definition of the variables see appendix. $\mathrm{N}=55$ cross section units. Least squares estimates with cross-section weights. ${ }^{* * *},(* *),(*)=$ significant at the $1 \%,(5 \%),(10 \%)$ level. Instruments: $\log ($ distance $)$, common border, 1 period lagged $\log (\mathrm{sp}), 1$-period lagged $\log (\mathrm{fi})$, constant.

Source: Own calculations.

Table E7:

Cross section estimates of nominal wage per employee (log(nce)), IV estimates, dummy for the Netherlands included

\begin{tabular}{|l|c|c|c|c|c|c|}
\hline \multirow{2}{*}{} & \multicolumn{7}{|c|}{ Dependent variable: HP_Log(NCE) } \\
\cline { 2 - 7 } & $1990-1997$ & $1998-2007$ & $1990-1997$ & $1998-2007$ & $1990-1997$ & $1998-2007$ \\
\hline Constant & $1.002 *$ & $17.155^{* * *}$ & -0.171 & $23.713 * * *$ & $0.754 *$ & $17.217 * * *$ \\
\hline $\log (\mathrm{x})$ & $0.609 * * *$ & $-0.622^{* * *}$ & & & & \\
\hline $\log (\mathrm{m})$ & & & $0.739 * * *$ & $-1.004 * * *$ & & \\
\hline $\log (\mathrm{tt})$ & & & & & $0.651 * * *$ & $-0.657 * * *$ \\
\hline $\log (\mathrm{sp})$ & $0.975^{* * *}$ & $-5.542^{* * *}$ & $1.444 * * *$ & $-7.984 * * *$ & $1.083 * * *$ & $-5.576^{* * *}$ \\
\hline $\log (\mathrm{fi})$ & $-1.175^{* * *}$ & $0.496^{* * *}$ & $-1.072^{* * *}$ & $0.432^{* * *}$ & $-1.173 * * *$ & $0.549 * * *$ \\
\hline Neth_dum & -0.031 & $1.589 * * *$ & -0.006 & $2.148 * * *$ & -0.037 & $1.867 * * *$ \\
\hline R2 adj. & 0.979 & 0.673 & 0.982 & 0.864 & 0.972 & 0.822 \\
\hline Nobs & 55 & 55 & 55 & 55 & 55 & 55 \\
\hline
\end{tabular}

For a definition of the variables see appendix. $\mathrm{N}=55$ cross section units. Least squares estimates with cross-section weights. ${ }^{* * *},(* *),(*)=$ significant at the $1 \%,(5 \%),(10 \%)$ level. Instruments: $\log ($ distance $)$, joint border, 1 -period lagged $\log (\mathrm{sp})$, 1-period lagged $\log (\mathrm{fi})$, constant.

Source: Own calculations. 
Table E8:

Cross section estimates of unit labor costs $(\log (\mathrm{ulc}))$, IV estimates (with dummy for The Netherlands)

\begin{tabular}{|l|c|c|c|c|c|c|}
\hline & \multicolumn{7}{|c|}{ Dependent variable: HP_Log(ULC) } \\
\cline { 2 - 7 } & $1990-1997$ & $1998-2007$ & $1990-1997$ & $1998-2007$ & $1990-1997^{\mathrm{a}}$ & $1998-2007^{\mathrm{a}}$ \\
\hline Constant & 0.519 & -6.173 & -1.458 & $-10.908^{* * *}$ & -0.867 & $-14.971^{* * *}$ \\
\hline $\log (\mathrm{x})$ & $0.664^{* * *}$ & $0.712^{* * *}$ & & & & \\
\hline $\log (\mathrm{m})$ & & & $0.922^{* * *}$ & $0.856^{* * *}$ & & \\
\hline $\log (\mathrm{tt})$ & & & & & $0.902^{* * *}$ & $1.042^{* * *}$ \\
\hline $\log (\mathrm{sp})$ & $1.298^{* * *}$ & 2.495 & $2.066^{* * *}$ & $4.305^{* * *}$ & $1.925^{* * *}$ & $5.582^{* * *}$ \\
\hline $\log (\mathrm{fi})$ & $-1.414^{* * *}$ & $-0.605^{* * *}$ & $-1.086^{* * *}$ & $-0.243^{* * *}$ & $-1.295^{* * *}$ & $-0.400^{* * *}$ \\
\hline Neth_dum & 0.188 & $0.227^{* *}$ & 0.005 & -0.278 & 0.061 & -0.381 \\
\hline R2 adj. & 0.886 & 0.985 & 0.996 & 0.937 & 0.895 & 0.909 \\
\hline Nobs & 55 & 55 & 55 & 55 & 55 & 55 \\
\hline
\end{tabular}

For a definition of the variables see appendix. $\mathrm{N}=55$ cross section units. Least squares estimates with cross-section weights. ${ }^{* *},(* *),(*)=$ significant at the $1 \%,(5 \%),(10 \%)$ level. Instruments: $\log ($ distance), joint border, 1 -period lagged $\log (\mathrm{sp})$, 1-period lagged $\log (\mathrm{fi})$, constant. a) as additional instrument $\log (\operatorname{tt}(-1))$ has been used.

Source: Own calculations. 


\section{Appendix F: Regression results with HP-filtered data, The Netherlands excluded $(\mathbf{N}=45)$}

Table F4:

Instrumental variable estimates of relationships between selected wage variables and trade intensity measures, $\mathrm{N}=45$

\begin{tabular}{|l|c|c|c|c|c|c|}
\hline \multirow{2}{*}{} & \multicolumn{2}{|c|}{ HP_Log(RCE) } & \multicolumn{2}{c|}{ HP_Log(NCE) } & \multicolumn{2}{c|}{ HP_Log(ULC) } \\
\cline { 2 - 7 } & $1990-1997$ & $1998-2007$ & $1990-1997$ & $1998-2007$ & $1990-1997$ & $1998-2007$ \\
\hline $\log (\mathrm{x})$ & $0.418^{* * *}$ & $0.456 * * *$ & $0.400 * * *$ & $-0.044 * *$ & $0.385 * * *$ & 0.355 \\
\hline Adj. $R 2$ & 0.375 & 0.957 & 0.689 & 0.108 & 0.419 & 0.893 \\
\hline $\log (\mathrm{m})$ & $0.557 * * *$ & $0.293 * * *$ & $0.594 * * *$ & $-0.176 * * *$ & $0.715 * * *$ & 0.330 \\
\hline Adj. $R 2$ & 0.848 & 0.642 & 0.671 & 0.450 & 0.461 & 0.918 \\
\hline $\log (\mathrm{tt})$ & $0.479 * * *$ & $0.434 * * *$ & $0.505 * * *$ & $-0.125 * * *$ & $0.649 * * *$ & $0.406 * * *$ \\
\hline Adj. $R 2$ & 0.413 & 0.857 & 0.652 & 0.440 & 0.785 & 0.911 \\
\hline
\end{tabular}

Constant term is not reported. For a definition of the variables see appendix. $\mathrm{N}=55$ cross section units. $*^{* *},\left({ }^{*}\right),\left({ }^{*}\right)$ $=$ significant at the $1 \%,(5 \%),(10 \%)$ level. Instruments: the distance measure and the dummy variable indicating a joint border or not, the dummy for the Netherlands, constant term, one period lagged explanatory variable.

Source: Own calculations.

Table F5:

Estimates of the impact of financial integration on sector specialization $(\mathrm{N}=45$, without The Netherlands)

\begin{tabular}{|l|l|l|c|c|l|}
\hline & Constant & $\log (\mathrm{FI})$ & $\mathrm{R} 2(\operatorname{adj})$. & Period & \multicolumn{1}{|c|}{ Instruments } \\
\hline 1 & $3.649 * * *$ & $0.132 * * *$ & 0.504 & $1980-1989$ & OLS \\
\hline 2 & $3.498 * * *$ & $0.172 * * *$ & 0.925 & $1990-1997$ & OLS \\
\hline 3 & $3.594 * * *$ & $0.188 * * *$ & 0.917 & $1990-1997$ & IV: const, $\log (\mathrm{FI}(-1))$ \\
\hline 4 & $3.619 * * *$ & $0.054 * * *$ & 0.414 & $1998-2007$ & OLS \\
\hline 5 & $3.753 * * *$ & $0.148 * * *$ & 0.688 & $1998-2007$ & IV: const, $\log (\mathrm{FI}(-1))$ \\
\hline
\end{tabular}

$* * *=$ significant at the $1 \%$ level; OLS $=$ ordinary least squares regression; IV = instrument variable estimation. Estimation with cross section weights.

Source: Own calculations. 
Table F6:

Cross section estimates of real wages, IV estimates, The Netherlands excluded

\begin{tabular}{|l|c|c|c|c|c|c|}
\hline \multirow{2}{*}{} & \multicolumn{7}{|c|}{ Dependent variable: HP_Log(RCE) } \\
\cline { 2 - 7 } & $1990-1997$ & $1998-2007$ & $1990-1997$ & $1998-2007$ & $1990-1997$ & $1998-2007$ \\
\hline Constant & -0.949 & $8.530 * * *$ & -0.115 & $20.491^{* * *}$ & -0.788 & $11.283^{* * *}$ \\
\hline $\log (\mathrm{x})$ & $0.719 * * *$ & -0.109 & & & & \\
\hline $\log (\mathrm{m})$ & & & $0.869^{* * *}$ & $-0.453^{* * *}$ & & \\
\hline $\log (\mathrm{tt})$ & & & & & $0.746^{* * *}$ & -0.195 \\
\hline $\log (\mathrm{sp})$ & $1.518^{* * *}$ & $-2.589^{* * *}$ & $1.404^{* * *}$ & $-6.458^{* * *}$ & $1.479 * * *$ & $-3.458^{* * *}$ \\
\hline $\log (\mathrm{fi})$ & $-0.749^{* * *}$ & -0.066 & $-0.387^{* * *}$ & -0.025 & $-0.657^{* * *}$ & -0.023 \\
\hline R2 adj. & 0.587 & 0.910 & 0.747 & 0.902 & 0.924 & 0.427 \\
\hline Nobs & 45 & 45 & 45 & 45 & 45 & 45 \\
\hline
\end{tabular}

For a definition of the variables see appendix. $\mathrm{N}=55$ cross section units. Least squares estimates with cross-section weights. ${ }^{* *},(* *),(*)=$ significant at the $1 \%,(5 \%),(10 \%)$ level. Instruments: $\log ($ distance $)$, common border, 1 period lagged $\log (\mathrm{sp}), 1$-period lagged $\log (\mathrm{fi})$, constant.

Source: Own calculations.

Table F7:

Cross section estimates of nominal wage per employee (log(nce)), IV estimates, The Netherlands excluded

\begin{tabular}{|l|r|r|r|r|r|c|}
\hline & \multicolumn{7}{|c|}{ Dependent variable: HP_Log(NCE) } \\
\cline { 2 - 7 } & $1990-1997$ & $1998-2007$ & $1990-1997$ & $1998-2007$ & $1990-1997$ & $1998-2007$ \\
\hline Constant & $2.957 * * *$ & -0.161 & $2.039 * * *$ & $-4.345^{* * *}$ & $2.873^{* * *}$ & -4.215 \\
\hline $\log (\mathrm{x})$ & $0.583 * * *$ & -0.294 & & & & \\
\hline $\log (\mathrm{m})$ & & & $0.919 * * *$ & $-0.157 * * *$ & & \\
\hline $\log (\mathrm{tt})$ & & & & & $0.710^{* * *}$ & -0.168 \\
\hline $\log (\mathrm{sp})$ & $0.244^{* *}$ & -0.371 & $0.823 * * *$ & $0.947 * * *$ & $0.379 * *$ & 0.965 \\
\hline $\log (\mathrm{fi})$ & $-0.741^{* * *}$ & 0.048 & $-0.432^{* * *}$ & -0064 & $-0.642^{* * *}$ & 0.022 \\
\hline R2 adj. & 0.905 & 0.743 & 0.814 & 0.440 & 0.953 & 0.109 \\
\hline Nobs & 45 & 45 & 45 & 45 & 45 & 45 \\
\hline
\end{tabular}

For a definition of the variables see appendix. $\mathrm{N}=55$ cross section units. Least squares estimates with cross-section weights. ${ }^{* * *},(* *),(*)=$ significant at the $1 \%,(5 \%),(10 \%)$ level. Instruments: $\log ($ distance $)$, joint border, 1 -period lagged $\log (\mathrm{sp}), 1$-period lagged $\log (\mathrm{fi})$, constant.

Source: Own calculations. 
Table F8:

Cross section estimates of unit labor costs $(\log (\mathrm{ulc}))$, IV estimates (The Netherlands excluded)

\begin{tabular}{|l|c|c|c|c|c|c|}
\hline & \multicolumn{7}{|c|}{ Dependent variable: HP_Log(ULC) } \\
\cline { 2 - 7 } & $1990-1997$ & $1998-2007$ & $1990-1997$ & $1998-2007$ & $1990-1997^{\mathrm{a}}$ & $1998-2007^{\mathrm{a}}$ \\
\hline Constant & $2.951^{* *}$ & -19.311 & 1.801 & -22.343 & 2.186 & $-21.104^{* * *}$ \\
\hline $\log (\mathrm{x})$ & $0.576^{* * *}$ & $0.929^{* *}$ & & & & \\
\hline $\log (\mathrm{m})$ & & & $0.856^{* * *}$ & $1.124^{* * *}$ & & \\
\hline $\log (\mathrm{tt})$ & & & & & $0.803^{* * *}$ & $1.051^{* * *}$ \\
\hline $\log (\mathrm{sp})$ & 0.350 & 6.542 & $0.942^{* * *}$ & $7.946^{* * *}$ & $0.767^{*}$ & $7.298^{* * *}$ \\
\hline $\log (\mathrm{fi})$ & $-0.955^{* * *}$ & $-0.620^{* *}$ & $-0.611^{* * *}$ & -0.135 & $-0.718^{* * *}$ & $-0.443^{* * *}$ \\
\hline R2 adj. & 0.852 & 0.909 & 0.997 & 0.951 & 0.939 & 0.998 \\
\hline Nobs & 45 & 45 & 45 & 45 & 45 & 45 \\
\hline
\end{tabular}

For a definition of the variables see appendix. $\mathrm{N}=55$ cross section units. Least squares estimates with cross-section weights. ${ }^{* * *},(* *),(*)=$ significant at the $1 \%,(5 \%),(10 \%)$ level. Instruments: $\log ($ distance), joint border, 1 -period lagged $\log (\mathrm{sp}), 1$-period lagged $\log (\mathrm{fi})$, constant. a) as additional instrument $\log (\operatorname{tt}(-1))$ has been used.

Source: Own calculations. 